\title{
İNSAN YAĞMASI (SÖMÜRÜSÜ) SUÇU (TCK m. 201b)
}

\author{
Yrd.Doç.Dr. Mahmut KOCA*
}

\section{GİRiş}

TBMM tarafından 3.8.2002 tarihinde kabul edilen 4771 sayılı "Çeşitli Kanunlarda Deģişiklik Yapılmasına tliş̧in Kanun"un' 2. maddesinin (B) bendi ile, Türk Ceza Kanununa 201. maddeden sonra gelmek ïzere iki yeni madde eklenmiştir. Bu maddelere $201 \mathrm{a}$ ve $201 \mathrm{~b}$ numaraları verilmiştir. Bunlardan 201a maddesinde "göçmen kaçakçılığı", 201b maddesinde ise "insan yağması" suçu düzenlenmektedir.

Her iki suç tipi de kanunumuzda daha önce yer almayan suçlardır. Bu suçların, Türkiye tarafından imzalanmış bulunan "Sınıraşan Örgütlü Suçlara Karşı Birleşmiş Milletler Sözleşmesi”ne Ek "Kara, Deniz ve Hava Yoluyla Göçmen Kaçakçılığına Karşı Protokol" ile "Insan Ticaretinin, Özellikle Kadın ve Çocuk Ticaretinin Önlenmesine, Durdurulmasına ve Cezalandırılmasına İliş̧in Protokol"ün gereğini yerine getirmek ïzere düzenlendiği, yasanın gerekçesinde belirtilmiştir ${ }^{2}$. Gerekçede ayrıca, 201b maddesinde düzenlenen suç tipine ilişkin olarak, şu açıklama yer almaktadır: "Şimdiye kadar özellikle kadın ve çocukların sömürülmelerini önlemek ve bu eylemlerle mücadele etmek üzere meydana getirilmiş çeşitli milletlerarası sözleşmeler imzalanmış, kararlar alınmıştır. Ancak anılan Protokolün imzalanmasından önce insan ticaretinin bütün yönlerini gözönünde bulunduran ortak bir metin yoktu. 1990'lı yıllardan itibaren suç örgütlerinin etkinliklerini sınırlar ötesi alana genişleterek, özellikle kadın, çocuk ve insan ticaretini örguttledikleri ve insanları bu uygar dünyada adeta esarete tabi

\footnotetext{
* Atatürk Universitesi Erzincan Hukuk Faküiltesi Ceza ve Ceza Usul Hukuku Öğretim Óyesi.

${ }^{1}$ RG. 9.8.2002, sy.24841.

${ }^{2}$ Kanun tekJifi ve gerekçesi jçin bkz. http://www.tbmm.gov.ț/sirasayi/dönem 21/vilo1 $1 \mathrm{ss} 890 \mathrm{~m} . \mathrm{htm}$.
} 
kıldıkları görülmektedir. Iște bu nedenle, Protokolün öngördüğü suçlara hukuk sistemimizde yer verilmesi uygun görülmüş̧ür".

Yasa koyucunun bu fiillerin ihlal ettiği hukuksal değerlerin ceza hukuku vasıtasıyla korunmasını önemseyerek suç alant oluşturması, bizce de yerinde olmuştur. Gerçekten özellikle göçmen kaçakçılığı bakımından ülkemizin Asya ile Avrupa arasında bir köprü oluşturduğu, bundan özellikle suç örgütlerinin büyük menfaat sağladıkları, yasal olmayan yollarla gerçekleştirilen bu tür kaçakçılık eylemlerinin çok sayıda insanın yaşam ve beden bütünliiğü bakımından onarımaz zararlara yol açtığı basın ve yayın organlarında sıklıkla yer almaktadır ${ }^{3}$. Aynı şekilde ve özellikle güçsïz ve çaresiz insanlarm iradeleri üzerinde tesir eden araçlar vasıtasıyla ve değişik maksatlarla sömürülddükleri de bilinen hususlardır. İşte bu tür fiillerin önlenmesi amacıyla ve uluslararası yükümlülük gereği yasakoyucu 201 a ve $201 \mathrm{~b}$ maddelerini düzenleme ihtiyacı hissetmiştir.

Biz bu çalışmada $201 \mathrm{~b}$ maddesinde düzenlenen insan yağması (sömürüsü) suçunu inceleyeceğiz. Bu suçun insan ticareti yerine. insan yağması veya sömürüsü olarak adlandırılmasının daha yerinde olduğunu düşüniiyoruz. Çünkü suç tipinde, eylemin, maddi menfaat sağlamak maksadtyla yapılmasına bir unsur olarak yer verilmemiştir. Her ne kadar suçun işlenmesinden fail dolaylı veya doğrudan bir menfaat sağlayabilirse de, eylenin cezalandırılmasının asıl nedeni, insanın alçaltılması, kişiliğinin yok sayılması ve onun adeta bir eşya gibi yağmanın konusu haline getirilmesidir. Klasik yağma suçunda (TCK m.495) kişiye karşı cebir veya tehditle bir eşya alınırken, o eşya üzerinde fiili hakimiyet kurulurken, $201 \mathrm{~b}$ maddesinde cebir veya tehdit ya da iradeyi etkileyen diğer araçlarla bir insan üzerinde belirli maksatlarla fiili hakimiyet kurulmaktadır.

\section{I- GENEL AÇIKLAMALAR}

TCK'nun 201b maddesine göre "Zorla çalsşırmak veya hizmet ettirmek, esarete veya benzeri uygulamalara tabi kilmak, vïcut organlarnin verilmesini saglamak maksadtyla, tehdit, baskt, cebir veya şiddet uygulamak, nüfuzu kötiiye kullanmak, kandırmak veya kişiler izzerindeki denetim olanaklarından veya çaresizliklerinden yararlanarak ruzalarin elde etmek suretiyle kişileri tedarik eden, kaçıran, bir yerden başka bir yere götïren veya sevk eden, barmdtran kimseye beş ylldan on yla kadar ăğ hapis ve bir milyar liradan az olmanak üzere ağır para cezast verilir.

\footnotetext{
${ }^{3}$ Benzer değerlendirme kanun teklifinin gerekçesinde de belirtilmektedir. TBMM, Dönem:21, Yasama Yilı 4, S. Sayısı: $890(\mathrm{bkz}$. http://www.tbmm.gov,tr/sirasayi/dönem21/vil(0)/ss 890 m.htm.).
} 
Birinci fikrada belirtilen amaçlarla girişilen ve suçu oluşturan eylemler var olduğu takdirde, mağdurun rizast yok saytlir.

Onsekiz yaşın doldurmamtş çocuklartn birinci fikrada belirtilen maksatlarla tedarik edilmeleri, kaçırlmalart, bir yerden diğer bir yere götürülmeleri veya sevk edilmeleri veya barındtrlmalart hallerinde suça ait araç fiillerden hiçbirisine başvurulmuş olmasa da faile birinci fikrada belirtilen cezalar verilir.

Yukarıdaki fıkralarda yazıll suçlar örgütlï olarak işlendiği takdirde faillere verilecek cezalar bir kat arttrlarak hükmolunur"

201 b maddesi, kanunumuzun cürümlere ait ikinci kitabmın "Hürriyet Aleyhine Işlenen Cürümler" başlığını taşıyan ikinci babının, "İ̧̧ ve Çalışma Hürriyeti Aleyhindeki Cürümler" başlıklı altıncı faslına ilave edilmiştir. Yasa koyucunun 201b maddesinde yer alan suçu "Hürriyet Aleyhinde İşlenen Cứrümler" babında đüzenlemesi isabetli olmakla birlikte, bu suça altıncı fasılda yer verilmesi doğru olmamıştır. Çünkü bu suç ile çalışma özgürlüŭgu arasında doğrudan bir ilişki kurmak mümkün değildir. Her ne kadar "zorla çalıştırmak veya hizmet ettirmek" maksadı suç tipinde yer almakta ise de, suçun oluşabilmesi bu maksadın gerçekleşmesine bağlı değildir. Insan yağması suçu, daha çok, 179. ve 188. maddelerde düzenlenen hürriyeti tahdit ve cebir kullanma suçlarının özel bir görünümü niteliğine sahiptir". Bu itibarla suça "Şahsın Hürriyeti Aleyhinde Cürümler" fasłlında yer verilmesi daha isabetli olurdu.

Nitekim, "esarete koymak" şeklinde bir suça, esasen kanunumuzun mehazını oluşturan 1889 tarihli Italyan Ceza Kanunu, "Şahsın Hürriyeti Aleyhinde Cürümler" faslında ve 145. maddesinde yer vermişti. Bu hükümde "Her kim bir şahsı esarete veya buna mümasil bir vaziyete koyarsa on iki seneden yirmi seneye kadar ağır hapis ile cezalandırılır" denilmekteydis. Bir kimseyi köle haline veya buna benzer bir duruma getirme fiillerini düzenleyen bu madde, TCK'ya alınmamıştır. Ancak doktrinde, mehazdaki bu maddenin kanunumuza alınmamış olmasının, bu tür eylemlerin kanunumuzun 179. maddesini ihlal edeceğinden, bir boşluk yaratmayacă̆ belirtilmiş̧ir $^{6}$.

\footnotetext{
${ }^{4}$ Adolf Schönke/Horst Schröder, Strafgesetzbuch Kommentar, 20. Auflage, München, $1980, \$ 234, \mathrm{kn} .1$.

${ }^{5}$ Bkz. Majno, Ceza Kanunu Şerhi. Türk ve İtalyan Ceza Kanunları, C.2, Ankara, 1978, s.98.

- Mehmet Emin Artuk/Ahmet Gökcen/A. Caner Yeniduinya, Ceza Hukuku Özel Hükümler, 3. Baskı, Ankara, 2002, s.48; Faruk Erem. Ümanist Doktrin Açısından Türk Ceza Hukuku, Özel Hükümler, C.llı, 3. Baskı, Ankara, 1985, s.229. Majno da ayn kanaattedir. Yazar 145, maddenin düzenlemesinden kanun koyucunun maksadıntn ne olduğunun
} 
Gerçekten 201b maddesinde düzenlenen suçta yer alan araç hareketlere baktığımızda, bunların kişi özgürlliğüne yönelik saldırıda kullanılan temel araçlar olduğunu görürüz. Maddede, belirli maksatlarla, kişileri tedarik etmenin, kaçırmanm, bir yerden başka bir yere götürmenin, sevk etmenin veya barındırmanın, mağdur üzerinde tehdit, baskı, cebir veya şiddet uygulamak, nüfuzu kötüye kullanmak, kandırmak veya kişiler üzerindeki denetim olanaklarindan veya çaresizliklerinden yararlanarak rızalarm elde etmek suretiyle işlenmesi gerekmektedir. Maddede geçen baskı, tehdit, cebir veya şiddet ve kandırmak hareketleri, kişi özgürlüuğüne yönelik tecavüzde kullanılan esaslı araçlar olarak kabul edilmektedir ${ }^{7}$. Bir başka ifade ile bu araçlar, özgürlïge yönelik suçlarda ya unsur ya da ağırlatıcı sebep olarak yer almakta ve bu vasıtalarla kişi özgürliuğüne saldırıda bulunulmaktadır.

Ancak birbiriyle ilgisi olmayan maksatlarm aynı maddede belirtilmesi ve bunların aynı suç altında birleştirilmesi kanaatimizce hatalı olmuştur. Özellikle vücut organlarının verilmesi maksadıyla eylemin gerçekleştirilmesj ile diğer maksatlar arasında bir ilişki yoktur. Özgürlüge yönelik suçlarda saik unsuru, bu tïr suçların birbirinden ayırt edilmesinde ve korunan hukuksal değer önceliğine göre kanunumuzun hangi babının hangi faslına yerleştirileceğinde gözönünde tutulması gereken en önemli husustur. Sözgelimi bir kadını cebir ve şiddet, tehdit veya hile ile şehvet hissi veya evlenme maksadryla kaçırmak umumi adap ve aile nizamı aleyhinde düzenlenen bir cürüm iken (TCK m.429), aynı kadmın haksız bir menfaat elde etmek maksadıyla kaçırılması malvarlığına karşı (TCK m.499), herhangi bir maksat olmaksızın kaçırılması ise özgürlüğe karşı (TCK m.179/1) suç oluşturmaktadır. Oysa 201b maddesinde yer verilen maksatlardan hiçbirisinin iş ve çalışma özgürlïğ̈ü ile bir ilgisi bulunmamaktadır. $\mathrm{Bu}$ nedenle suçun kanunumuzun 2 , babının üçüncü faslında, şahsın hürriyeti aleyhinde cürümler arasında düzenlenmesi gerekirdi. Bu fasıl içerisinde de, kanaatimizce 179 . veya 188 . maddeden sonra gelmek üzere $179 \mathrm{a}$ ya da $188 \mathrm{a}$ numarası altında yer alması daha isabetli olurdu.

anlaşılmadığını ve esasen 146 . (TCK m.179) maddenin bu maddeyi kapsadığını ve dolayısıyla söz konusu hükmün lüzumsuz olduğunu belirtmektedir (Majno, s. 100).

${ }^{7}$ Schönke/Schröder. Vorbem. $\S \$ 234$ ff, kn .5. 


\section{II- SUÇUN KONUSU VE KORUNAN HUKUKSAL DEĞER}

\section{1- Suçun Konusu}

Suçun konusu denilince, bundan suç teşkil eden eylemin üzerinde etkisini gösterdiği kişi veya şey anlaşılır ${ }^{8}$. İnsan yağması suçunun konusunu insan oluşturmaktadır. Bu insan, maddede belirtilen araçlar vasıtasıyla yine maddede belirtilen maksatlarla tedarik edilen, kaçırılan, başka bir yere götuirülen veya barındırılan herhangi bir kimsedir. Bir başka ifade ile maddede belirtilen maksatlarla sömürülen insan suçun konusunu oluşturmakta ve bu insanın, yaşı, cinsiyeti, milliyeti veya diğer özellikleri önem taşımamaktadır. Fakat 18 yaşını doldurmamış olanlara karşı suçun işlenmesi halinde, araç hareketler kullanılmasa da, eylemin suç teşkil edeceği maddede belirtilmiştir.

\section{2- Korunan Hukuksal Değer}

Bilindiği gibi suç teşkil eden her eylem, mutlaka, en az bir hukuksal değerin ihlalini oluşturur". Ancak yasakoyucu bazen bir fiili suç haline getirmekle birden çok hukuksal değeri de korumak isteyebilir ${ }^{10}$. Hukuksal değerler "duyu organları aracılığıyla algılanabilir varlıklar olarak değil, toplum içindeki güvenliğe, sükuna ve var olmanın onuruna istinat eden toplumsal düzenin manevi değerleri olarak anlaşılmalıdır"'l. Bir başka deyişle bu değerler, toplumsal düzen açısından korunması gereken, bu düzenin devamı için geçerliliği zorunlu olan, ideal, manevi ve soyut degerlerdir ${ }^{12}$.

Kanunumuza yeni giren $201 \mathrm{~b}$ maddesinin kanuna konulduğu yere bakılırsa, yasa koyucunun bu suç ile iş ve çalışma özgürliuğünü korumak istediği sonucuna varılabilecektir. Gerçekten bir suçun kanununda düzenlendigi yer, o suç ile korunmak istenen hukuksal değerin belirlenmesinde gözönünde bulundurulması gereken esaslı noktalardan birisidir. Ancak çalışma özgürlüğünün ihlalinden bahsedebilmemiz için, öncelikle bu özgürlüğün bulunması ve bunun cebir, şiddet veya tehdit

\footnotetext{
${ }^{8}$ Nevzat Torosıu, Cürümlerín Tasnifj Bakımından Suçun Hukuki Konusu, Ankara, 1970, s.185; Yener Unver, Ceza Hukukuyla Korunmast Amaçlanan Hukuksal Deł̌ger, Ankara, 2003, s.133, 142.

${ }_{9}^{9}$ Kayshan İçel/Füsun Sokullu-Akunci/İzzet Özgenç/Adem Sözïer/Fatih S. Mahmutoğlu/Yener Ưnver, İçel Suç Teorisi, 2. Kitap. 2. Bası, İstanbul, 2000, s.87; Sulhi Dönmezer/Sahir Erman. Nazari ve Tatbiki Ceza Hukuku, Genel Kısım, C.I. 13. Bası, İstanbul, 1997, s.333; Izzet Özenç/Cumhur Şahin, Uygulamalı Ceza Hukuku, 3. Bası, Ankara, 2001, s.111; Ünver. s.135.

10 Toroslu, s.288; Özgenৎ̧/Şahin, s.111; Ünver, s.109.

" Ünver, s.130.

${ }^{12}$ Özgenç/Şahin, s.110.
} 
yoluyla men veya tahdit edilmesi gerekir (m.201). Halbuki $201 \mathrm{~b}$ maddesinde düzenlenen suçta, fail bir kimsenin iş ve çalışma özgürlüğgünü değil, bizatihi kişisel özgürliuğünü ihlal etmektedir. Kişisel özgürlüge karşı suçların koruduğu hukuksal değer, genel olarak, iradi karar verme ve iradi hareket etme özgürlit̆üüüir ${ }^{1.3}$. Kişinin özgürlüğg̈une yönelik suçlar, doktrinde iç ve dış özgürlüğe yönelik olmak üzere ikiye ayrılmaktadır. Bu ayrıma göre kişilerin hareket serbestisini ortadan kaldıran veya sınırlandıran suçlar (örneğin hürriyeti tahdit (TCK m.179), kanunsuz hapis (TCK m.185) gibi) dış hürriyete: kişilerin hareket serbestilerini sumırlandırmayan ve fakat iradi karar verme özgürlüğtinü sınırlandıran suçlar ise (örneğin tehdit (TCK m.191. cebir kullanma (TCK m.188) gibi) iç hürriyete karş1 suçlardır ${ }^{1+}$. Kanaatimizce insan yağması suçu, bu ayrım çerçevesinde, bireyin hem iç özgürlügüune (baskı, cebir, şiddet, tehdit ve kandırma) hem de dış özgürlüğüne (kaçırma, bir yerden diğer bir yere götürme) karşı işlenmektedir. Çünkü maddede kişinin, tehdit, baskı, cebir ve şiddet veya kandırma gibi iradeye tesir eden araçlarla failin maksadı doğrultusunda zorlanmak suretiyle kaçırılması tedarik edilmesi, götürülmesi veya sevk edilmesi aranmaktadır. Böylece araç hareketlerle kişinin irade özgürlǚ̆ŭ ve bu çerçevede serbestçe irade oluş̧urma, iradi karar verme ve iradi hareket etme özgürlükleri, kısaca kişinin kendi kaderine belirleme özgürlügüü, asıl hareketlerle de kişinin hareket serbestisi ihlal edilmiş olmaktadır.

Ancak belirtmek gerekir ki, insan yağması suçunda öncelikli korunaı hukuksal değger kişinin irade özgürlïğü olmakla birlikte, bu suç tipiyle başka değerler de korunmaktadır. Esasında bu suçla, Anayasanın 17. maddesinde ifadesini bulan "kişinin maddi ve manevi varlığını geliştirme" ve "insán haysiyetiyle bağdaşmayan bir muameleye tabi olmama" hakları ile, 18. maddesindeki "angarya yasağı" korunmakta, kısaca ve son tahlilde "insan haysiyeti"ni koruma amacı güdüImektedir. Suç tipindeki hareketlerin gayesine bakığımızda sözgelimi zorla çalıştırmak veya hizmet ettirmekle kişinin eme ğinin sömürüsï (angarya yasağının ihlali), esarete veya benzeri uygulamalara tabi kılmak maksadında bireyin haysiyetinin ihlali, vüicut organlarının verilmesini sağlamakla da kişinin hem beden bütünlüğünün hem de şahsiyet hakkının ihlali söz konusu olmaktadır. Bu durumda $201 \mathrm{~b}$. maddede birden çok hukuksal değerin korunduğu söylenebilecektir.

Kanaatimizce korunan öncelikli değer, bireyin irade özgürlüğüdür. Esasında insan haysiyeti değerinin, son tahlilde, "hür irade" olduğu söylenebileceğine ve insanı obje haline getiren ve kişiliği nedeniyle sahip olduğg değerin inkarı anlamına gelen her türlia işlem de insan haysiyetine

13 Johannes Wessels/Michael Hettinger, Strafrecht Besonderer Teil/1. Strattaten gegen Persönlichkeits- und Gemeinschaftswerte, 23.. neubearbeitete Auflage. Heidelberg, 1999. $5.89, \mathrm{kn} .368$; Schönke/Schröder, Vorbem. $\$ \$ 234 \mathrm{ff}, \mathrm{kn} .3 .4$.

${ }^{14}$ Erem, C.lll, s.227. 
aykırı olacağına göre ${ }^{15}, 201 b$ maddesinin "insan haysiyeti" değerini, insanın kişiliğini koruyan bir hüküm olduğu söylenebilecektir. Nitekim doktrinde kanunumuzun ikinci babının üçüncü faslında yer alan cürümlerle, kişinin maddi ve manevi özgürlüğünü̈n, diğer şahıslardan bağımsız kimliğinin korunduğu belirtilmektedir ${ }^{16}$.

\section{III- FAİL VE MAĞDUR}

\section{1- Fail}

Bu suçun faili herkes olabilir. Kanunumuz suçun faili bakımından herhangi bir özellik aramamıștır. Dolayısıyla memur veya mağdurun yakınları da suçun faili olabilir. Failin memur olması halinde, şartları varsa, TCK'nun 251 veya 281. maddeleri uygulanır.

\section{Mağdur}

Bir ceza normu tarafından korunan ve suç teşkil eden eylemle tecavüze uğrayan (zarara veya tehlikeye sokulan) hakkın süjesi, değerin veya yararın sahibi o suçun mağdurudur ${ }^{17}$. İnsan yağması suçunun mağduru, doğal anlamda irade özgürlïgüne sahjp olan her hangi bir kimsedir. Bu suçun mağdurunun hukuki anlamda temyiz gücüne sahip olması gerekli değildir. Aksine böyle bir yeteneğe sahip olmayan kişi de, tutum ve davranışlarını makul düşüncelerle belirleyemediği durumlarda dahi, iç dürtüleriyle bunları makul ölçüde gerçekleştirebileceği için. kendi kaderini belirleme yetkisine sahiptir. Suç baskı araçları ile bir kimseyi iradesine aykırı bir davranışa zorlama hareketleriyle işlenebileceğinden, sınırlı da olsa kendi kaderini belirleme yeteneğine sahip olan her insan bu suçun magduru olabilir ${ }^{18}$. Bu itibarla suçun mağduru bu yeteneğe sahip bir çocuk veya akıl hastası da olabilir.

Fakat 201b maddesinde mağdur bakımından yaşa göre bir ayrım yapılmış ve 18 yaşını doldurmamış küçük ve çocuklar üzerinde araç hareketler (tehdit, baskı, cebir, kandırma vb.) kullanılmamış olsa dahi suçun oluşacağı belirtilmiştir. Bir başka ifade ile, 18 yaşını doldurmamış olanların zorla çalıştırmak veya hizmet ettirmek, esarete veya benzeri uygulamalara tabi kılmak veya vücut organlarının verilmesini sağlamak maksadıyla, herhangi bir baskı aracı kullanmaksızın, kaçırılmaları, tedarik edilmeleri, başka bir yere götürülmeleri veya barındırılmaları halinde suç oluşacaktır

is Bahri Öztürk/Veli Özer Özbek/Mustafa Ruhan Erdem, Öztürk Uygulamalı Ceza Muhakemesi Hukuku, 6. Baskı, Ankara, 2001, s.137.

${ }^{16}$ Dogan Soyaslan. Ceza Hukuku Özel Hükủmler, 3. Baskı, Ankara, 1999, s.583.

${ }^{17}$ Toroslu. 5.176.

${ }^{1 R}$ Bkz. Erol Cihan, Cebir Kullanma Cürmi (TCK. m.188), jstanbul, 1978, s.49-51. 
(m.20lb/3). O halde bu suç tipi bakımından mağdurun yaşı önem taşımaktadır. Mağdur 18 yaşınt doldurmamışsa belirtilen maksatlardan biriyle kaçırılması veya tedarik edilmesi yeterli olmakta, 18 yaşını doldurmuşsa suçun oluşabilmesi için ayrıca iradeyi etkileyen araçların varlığ gerekmektedir.

Kanaatimizce bu düzenleme yerinde değildir. 18 yaşını doldurmamış çocuklar arasında da bir ayrım yapıliarak, 12 yaşından küiçük çocuklara karşı cebir, şiddet, tehdit, kandırma, baski gibi iradeyi etkileyen araç hareketlere başvurulmaksızın eylemin gerçekleştirilmesini suçun ağırlatıcı sebebi saymak, 12-18 yaş arasındaki çocuklar bakımından ise kanundaki diuzenlemeyi (20lb/3) kabul etmek daha yerinde olurdu.

\section{IV- SUÇUN UNSURLARI}

Kanunumuzun $201 \mathrm{~b}$ maddesinde belirtilen insan yağması suçunun unsurları şunlardır:

1) Failin herhangi bir kimseyi tedarik etmesi, kaçırması, bir yerden başka bir yere götürmesi, sevk etmesi veya barındırması,

2) Bu hareketlerin tehdit, baskı, cebir veya şiddet uygulamak, nüfuzu kötüye kullanmak, kandırmak veya kişiler üzerindeki denetim olanaklarından veya çaresizliklerinden yararlanarak rızalarını elde etmek suretiyle gerçekleştirilmiş bulunması,

3) Failde özel kastın varlığı yani tedarik, kaçırma, bir yerden başka bir yere götürme, sevk etme veya barındırmanın bir kimseyi zorla galısturmak veya hizmet ettirmek, esarete veya benzeri uygulamalara tabi kilmak veya väcut organlarmun verilmesini sağlamak maksadyla yapılmış olması. gerekir.

Bu unsurlardan ilk ikisi suçun maddi unsurunu, diğeri ise manevi unsurunu oluşturmaktadır. Şimdi bunları ayrı ayrı inceleyelim.

\section{1- Maddi unsur}

Suçun maddi unsurundan maksat, tipe uygun fiildir. Ceza hukukunda fiil denildiğinde ise, bundan hareket, netice ve bu ikisini birbirine bağlayan 
nedensellik bağı anlaşlılı. Bu üç alt unsur birlikte, suçun maddi unsurunu oluşturmaktadır ${ }^{19}$.

\section{a- Hareket Bakımından Suçun Özellikleri}

Hareket, insanın dış dünyada yapmak veya yapmamak şeklinde ortaya çıkan ve hukuki bir önemi bulunan iradi bir davranışıdır ${ }^{20}$. İnsan yağması suçu iki hareketli bir suçtur. Failin önce "tehdit, baskı, cebir veya şiddet uygulamak, nüfuzu kötüye kullanmak, kandırmak veya kişiler üzerindeki denetim olanaklarından veya çaresizliklerinden yararlanarak rızalarını elde etmek" şeklinde bir harekette bulunması gerekir. Ancak suçun oluşabilmesi için bu hareketlerin yapılması yeterli deģildir. Fail bu hareketler aracılı̆̆ıyla ikinci bir harekette daha bulunmalıdır. Bunlar da kişileri tedarik etme, kaçırma, bir yerden başka bir yere götürme, sevk etme veya barındırmadır. $O$ halde birinci hareketler, asıl hareketi yapmanın araci olmaktadırlar. Bu durumda suçun maddi unsuru, tehdit, baskı, cebir veya şiddet uygulamak, nüfuzunu kötüye kullanmak, kandırmak veya kişiler üzerindeki denetim olanaklarından veya çaresizliklerinden yararlanarak rızalarını elde etmek suretiyle kişilerin tedarik edilmesi, kaçınlması, bir yerden başka bir yere götürülmesi, sevk edilmesi veya bartndirılmastdtr. Ancak suçun konusunu oluşturan insanın 18 yaşını doldurmamış olması halinde, araç hareketlerden hiçbirisi yapılmamış olsa dahi suçun oluşacağını tekrar belirtmek gerekir $(201 \mathrm{~b} / 3)$.

Suç hareketin şekli bakımından icrai bir suçtur ${ }^{21}$. Kanunda belirtilen hareketler, ihmali bir davranışla gerçekleştirilemez. Failin aktif bir davranışta bulunması şartır. Hareketin önemi bakımından ise, kanun suçun hangi hareketlerle işlenebileceğini suç tipinde tek tek belirttiği için, bağhl hareketli bir suç söz konusudur ${ }^{22}$. Bu hareketler, bask1, tehdit, cebir ve şiddet, kandırma, nüfuzu kötẗye kullanma ve kişiler üzerinde denetim olanaklarından veya kişinin çaresizliğinden yararlanarak rızasımı elde etmek suretiyle kişilerin tedarik edilmesi, kaçırılması, bir yerden başka bir yere götürülmesi veya sevk edilmesi veya barındırılmasıdır. Burada sayılanların dışında bir hareketle bu suç işlenemez. Hareketin sayısı bakımından ise seçimlik hareketlidir ${ }^{23}$. Maddede belirtilen hareketlerden herhangi birinin

\footnotetext{
${ }^{19}$ Bkz. Dönmezer/Erman, C.I, s.366, 369; Mehmet Emin Artuk/Ahmet Gökcen/A. Caner Yenidünya, Ceza Hukuku Genel Hükümler, Birinci Kitap, Ankara, 2002, s.427.

${ }^{20}$ Dönmezer/Erman, C.I, s.370; Artuk/Gökcen/Yenidünya, Gene] Hükümler I, s.427; Bahri Öztürk/ Mustafa Ruhan Erdem/Veli Özer Özbek, Öztürk Uygulamalı Ceza Hukuku ve Emniyet Tedbirleri Hukuku, 5. Baskı, Ankara, 2001, s.122.

${ }^{21}$ Kavram hakkında bkz Dönmezer/Erman, C.I, s.376; Artuk/Gökcen/Yenidünya, Genel Hükimler I, s.437.

${ }^{22} \mathrm{Bkz}$. Dönmezer/Erman, C.I, \$.373; Artuk/Gökcen/Yenidünya, Genel Hükümler I, s.440 vd.

${ }^{23}$ Kavram için bkz. Dönmezer/Erman, C.I, s.373 vd.
} 
yapılması ile suç tamamlanır. Hepsinin birden yapılması durumunda ise, ortada yine de tek suç vardır ${ }^{24}$. Örneğin fail, mağduru hem tehdit ve hem de şiddet kullanarak tedarik ederek bir yerden başka bir yere götürse ve orada barındırsa, ortada tek bir insan yağması suçu vardır.

Suçlarım netice bakımından yapılan tasnifinde, insan yağması suçu, şekli bir suç görünümuindedir ${ }^{25}$. Maddede belirtilen maksatlardan herhanģi biriyle ve yine maddede belirtilen araçlardan birini kullanarak kişilerin tedarik edilmesi veya kaçırılması veya bir yerden başka bir yere götürülmesi veya sevk edilmesi veya barındırılması ile suç tamamlanır. Suçun oluşması için belirtilen hareketlerden ayrı bir neticenin gerçekleşmesi aranmamaktadır. Sözgelimi failin amacına ulaşması suçun varlığı için şart değildir. Bu itibarla da tedarik, kaçırma, başka bir yere götürme, sevk veya barındırma hareketi ile birlikte suç da oluşur. İnsan yağması suçunda bu hareketlerden her biri temadi edebileceğinden, suç mätemadi bir suştur. Tehlike suçu-zarar suçu ayrımında ${ }^{26}$ ise, insan yagması bir tehlike suçudur. Zira zarar suçlarmnda tipik eylemle suç konusunun bir zarara uğraması gerekir. Tehlike suçlarında ise, hareketten doğan neticenin suç konusu bakımından bir zarar tehlikesi oluşturması yeterlidir ${ }^{27}$.

\section{b- Suçın Maddi Unsurunu Oluşturan Araç Hareketler}

\section{aa- Genel Olarak}

Daha öncede belirttiğimiz gibi, insan yağması suçu araç ve amaç hareketlerle işlenebilen bir suçtur. Diğer iç hürriyete karşı işlenen suçlarda olduğu gibi (örneğin TCK m. 188, 192) bu suçta da, mağdurun, iradesi uzerinde baskı oluşturan bir takım hareketlerle, failin arzusu doğrultusunda motive edilmesi söz konusudur. Maddede bu hareketler sırasiyla tehdit, bask, cebir veya şiddet uygulamak, nïuzu kötiiye kullanmak, kandımak veya kişiler üzerindeki denetim olanaklartndan veya çaresizliklerinden yararlanarak rizaların elde etmek olarak belirtilmiştir.

\footnotetext{
${ }^{24}$ Timur Demirbaş, Ceła Hukuku Genel Hükümler, Ankara, 2002, s.194.

${ }^{2 s}$ Bkz. Dönmezer/Erman. C.I. s.381 vd.; Öztürk/Erdem/Özbek. Uygulamalı Ceza Hukuku. s.137.

26 Bu ayrım için bkz. İçel/Sokullu-Akıncı/Özgenç/S̈̈züer/Mahmutoğlu/Ünver. s.68; Artuk/Gökcen/Yenidünya, Genel Hükümler I, s.445; Nur Centel, Türk Cezà Hukukuna Giriş. İstanbul. 2001. s.197; Demirbaş, s.207; Özgenç/Şahin, s.131: Vesile Sonay Daregenli, "Tehlike Suçları”, Prof. Dr. Sahir Erman'a Armağan, jstanbul. 1999 s.163 vd.

27 İ̧̧el/Sokullu-Akmcı/Özgenç/Sözïier/Mahmutoğlu/Ünver s.68; Artuk/Gökcen/Yenidünya, Genel Hükummler I, s.445; Ozgenç/Şahin. s.131.
} 


\section{bb- Araç Hareketler}

Maddede belirtilen araç hareketlerin hepsini, mağdurun iradesi üzerinde baskı oluşturan hareketler olarak nitelendirmek mümkündür. Gerçekten suçun oluşabilmesi için mağdurun iradesi üzerinde bir etkinin oluşturulması gerekir. Bu etkiyi oluşturacak hareketler ise maddede tehdit, baskı, cebir veya şiddet uygulama, nüfuzu kötïye kullanma, kandırnta veya kişiler üzerindeki denetim olanaklarindan veya çaresizliklerinden yararlanarak rızalarını elde etme olarak belirtilmiştir. Diğer taraftan maddenin üçüncü fıkrası ile, 18 yaşını doldurmamış olanların belirtilen araç hareketlerle irade özgürlükleri üzerinde herhangi bir baskı oluşturulması aranmayacaktır. Bu kimseler bu tür hareketlere maruz kalmaksızın maddede belirtilen maksatlarla kaçırılmış, başka bir yere götürülmüş veya sevk edilmişseler suç oluşacaktır.

Maddede belirtilen cebir, şiddet, baskı, tehdit ve kandırma hareketleri, başkasının davranışı üzerine etki etmede birer araçtırlar ${ }^{28}$. Ancak söz konusu ortak özelliklerine rağmen, bu araçlar iradeyi etkileme biçimleri jtibariyle birbirlerinden farklı özelliklere sahiptirler. Cebir ve tehdit, hileden, zorlama etkisi nedeniyle farklılık taşır ${ }^{29}$. Esasında cebir kavramı, geniş anlamda, hem maddi (cebir ve şiddet), hem de manevi (tehdit) zorlamayı içerir ${ }^{30}$. Dolayısıyla gerek cebir, gerek tehdit, magdurun karar ve hareket etme özgürlügüü üzerinde zorlayıcı bir etki meydana getirerek, failce istenilen neticeyi sağlarlar. Bu araçlar iradeyi baskı altına alan, ona yön veren ve bu nedenle de irade özgürlügüune karşı tecavüz oluşturan bir nitelige sahiptirler ${ }^{3 \prime}$. Bu ortak özelliklerine rağmen cebir ve tehdit birbirinden farkl vasitalardir.

Cebir, genel olarak, özgürlüge karşı suçlar anlamında, halihazır, ciddi bir kötülü̈k yoluyla bir başkasının iradesi ve davranışları üzerinde zorlayıcı bir etki meydana getirilmesidir ${ }^{32}$. Tehdit ise, bir kimsenin korkutulmasina yönelik olarak, gelecekte yapılacak haksız bir kötülüğün, fenalığın herhangi bir şekilde bildirilmesidir ${ }^{33}$. Demek ki cebirde mağdurdaki zorlama etkisine failin mevcut, aktilel bir kötülügüün icrası neden olurken, tehditte gelecekte yapılacak bir kötülü̆gün bildirilmesi neden olmaktadır ${ }^{34}$. Fail, mağduru

${ }^{2 x}$ Schönke/Schröder, Vorbem. $\$ \S 234$ ff, kn.6.

${ }^{20}$ Schönke/Schröder, Vorbem. $\$ 234$ ff. kn.6.

${ }^{30}$ Erem, C.III, s.193, 258; Cihan, s.58; Artuk/Gökcen/Yenidünya, Özel Hükümler, s.6] .

${ }^{31}$ Soyaslan, s.585; Özenç/Sahin, s.406.

${ }^{32}$ Schönke/Schröder, Vorbem. $\$ \S 234$ ff, k.n.6.

${ }^{33}$ Wessels/Hettinger. s.97. kn.402; Artuk/Gökcen/Yenidünya, Özel Hükümler. s.61; Soyaslan, s.584; Durmuş Tezcan/Mustafa Ruhan Erdem, Teorik ve Pratik Ceza Özel Hukuku, 2.Bası. Izmir, 2002, s.47.

${ }^{34}$ Schönke/Schröder, Vorbem. \$§§ 234 ff, k.n.6. 
gelecekte bir haksızlığın, kötüliügün yapılacağı tehdidi ile korkutmak suretiyle onu kendi iradesine tabi olmaya manen icbar etmektedir. Ancak gerek cebir gerekse tehdit magdurun mevcut veya beklenen mukavemetini kırmak yada engellemek suretiyle, mağdurun iradesini failin iradesi doğrultusunda yönlendirmektedirler. İncelemekte olduğumuz suç bakımmdan cebir veya tehdit, mağduru ya aktiiel ya da gelecekte bir kötülüğe maruz kalmak veya failce istenilen duruma razı olmak seçenekleri arasında bırakmaktadır. Kötülükten korkan mağdur, failin arzusuna boyun eğecektir.

201b. madde anlamında cebir, mutlak (vis absoluta) ve zorlayıc1 (vis compulsiva) cebri kapsar. Bir başka ifade ile cebir, iradenin oluşumunu engelleyen (örneğin narkoz etkisi altında tutma, uyuşturucu madde, uyku hapı verme gibi) ya da mevcut iradenin harekete geçmesini (örneğin bağlama, tutma, odaya hapsetme gibi) mutlak olarak imkansız kılmak suretiyle icra edileceği gibi, mağdurun iradi karar özgürlüğünü ihlal eden bir davranıs yoluyla da gerçekleştirilebiliri ${ }^{35}$. Diğer taraftan 201b. maddede cebir, kişiye veya essyaya karşı kullanılabilir. Cünkü madde metninde cebirin kişiye karşı kullanılması gerektiği yönünde bir ibare mevcut değildir. Eşya üzerinde cebir, eşyanın tahribi, yapısının değiştirilmesi veya zarar görmesi durumunda vardır ${ }^{36}$. Ancak $201 \mathrm{~b}$ maddesi bakımından da eşya üzerinde kullanılan cebrin, eşya ile ilgisi olan kişiler üzerinde, failin maksadı doğrultusunda korku yaratacak nitelikte bulunması zorunludur. Dolayısıyla eşyaya karşı cebir mağdur üzerinde dolaylı bir tesir meydana getirmelidir ${ }^{37}$.

Ayrıca cebir veya tehdidin bizzat mağdura yönelmiş olması da şart değildir. Mağdurun iradesini etkileyerek istemediği bir davranışa onu zorlayabilecek herhangi bir kimseye karşı uygulanacak cebir veya tehdit de. yeterli sayılmalıdır. Örneğin fail oğlunu öldürmekle tehdit etmek suretiyle, babayı böbreğini vermek için, bulunduğu yerden başka bir yere götürürse, suç gerçekleşmiş olacaktır.

Zorlama araçlarından birisi de baskıdır. Baskı, bir kimsenin zor alında bulundurulması anlamına gelen bir kavramdır. Burada da mağdurun iradesine yönelik bir zorlama söz, konusudur. Bu zorlama, mağduru failin iradesine tabi otmaya motive etmektedir. Yasa koyucunun cebir, şiddet ve tehdidi saydıktan sonra, aynca baskı kavramını da kullanmıs olmasını, zorlama araçlarının alanını genişletmek olarak anlamak gerekir. Dolayısıyla, cebir veya tehdit boyutuna gelmemiş olan ve fakat irade üzerinde tesire neden olan her türlü zorlayıcı davranışlar bu kavramın içerisine girecektir.

\footnotetext{
${ }^{35}$ Schönke/Schröder. Vorbem. $\$ \$ 234$ fr, kn.13, 15; Wessels/Hettinger, s.96, kn.396; Tezcan/Erdem, s.46.

${ }^{36}$ Soyaslan. s.584; Cihan, s.78,

${ }^{37}$ Cihan, 5.78 .80 .
} 
Kandırmak ise, bir kimseyi aldatarak, yanıltarak bir şeye razı etmek, inandırmak demektir. Hilenin kaynağında aldatma vardır. Bir kimse diğerini belirli bir biçinde hareket etmeye sevk edecek bir yanılgıya soktugunda veya bunun şartlarını hazırladığında hile söz konusudur ${ }^{3 *}$. Bir başka ifade ile, bu tabirden, mağdurun iradesi izerine tesir eden ve yaptığı hareketin mahiyeti hakkında onu hataya düşüren her türlü hileli ve yalan vasıtaların kullanılmasını anlamak gerekir ${ }^{39}$. Failin, mağdurdan asıl maksadını gizleyerek yaptığı her türlü aldatıcı hareketler kandırma kavramı içerisine girer. Hile yapan, mağdurda o hareketi yaptığı takdirde kendi lehine bir davranışın oluşacağına inandırılmalıdır. Bu nedenle hilede, mağdurun yararına olan etkiler, sonuçlar ortaya konulmalı, o gerçek durumu bilseydi böyle bir harekette bulunması söz konusu olmamalıdır. Mağdur, hile yoluyla, gerçek hakkında hataya dürüldüğü, gerçek ondan gizlendiği için, kendisinden istenilen davranı̧̧ı gerçekleştirmekte ve böylece kişisel özgürlük de ihlal edilmiş olmaktadır. Her ne kadar hile de cebir teşkil eden hareketin maddi varlığı yoksa da, hilenin neticesi cebrinkinden farksızdır. Bir başka ifade ile cebirle hangi sonuca ulaşılacak idiyse, kandırma suretiyle de fail aynı sonuca ulaşmaktadır ${ }^{49}$. Kandırmanın varlı̆̆ı halinde mağdurun rızasından bahsetmek mümkün değildir ${ }^{41}$. Sözgelimi bir kimseyi yakalandığı hastalıktan kurtaracağını söyleyerek onu cerrahi bir müdahale için hastaneye yatırmaya ikna eden failin, yapılan ameliyatla o kimsenin böbreğinin alınmasını sağlaması gibi. Keza failin, ücret mukabili iş bulduğunu söyleyerek, bir kimseyi bir başkasının veya kendisinin emrinde zorla çalıştırmaya tabi tutması halinde de, 201b madde ihlal edilmiş olur.

Nïfuzu kötüye kullanmak suretiyle suçun işlenebilmesi için, öncelikle kötiiye kullanılacak bir nüfuza sahip olunması gerekir. Nüfuz kelimesi, sözlükte, içine geçme, işleme, söz geçirme, geçerli, cari, meri olma ve bir kimsenin emir ve hükümlerinin işlemesi, geçerli olması; nüfuz sahibi olmak ise, sözü geçmek, itibarlı olmak anlamlarına gelmektedir ${ }^{42}$. Bu durumda nüfuz sahibi olan kişi, mağdurun sözünü tuttuğu, mağdurun kendisine minneti olan şahıs olmaktadır ${ }^{43}$. Bu kimseler çoğu zaman mă̆durun annesi, babası, kardeşi, oğlu, kızı, eşi gibi yakınları olabileceği gibi, fiili ilişkiler içerisinde oldugu amca, dayı, hala, teyze gibi akrabaları ve patron, ögretmen, mürebbi, hizmetkar gibi kişiler de olabilir. Işste fail ile mağdur arasındaki ailevi, iş veya diğer herhangi bir sebeple mevcut bir ilişkiyi mağdur üzerinde kullanmak suretiyle onu etki altma alıp, belirtilen maksatlar için bu etkinin

\footnotetext{
${ }^{3 \pi}$ Cihan, s.62.

${ }^{30}$ Sulhi Dönmezer. Umumi Adab ve Aile Nizamı Aleyhinde Cürümler, Istanbul. 1950, s.250.

${ }^{40}$ Cihan, s.62-63.

* Ayhan Ö́nder, Türk Ceza Hukuku Özel Hükümler, 4. Bası, İstanbul, 1994, s.597.

${ }^{42}$ Büyưk Türkçe Sözlük (Hażriayan: D. Mehmet Doğan), 11. Bask, 1stanbu]. 1996, s.851; Türkçe Sözlük 2 (Türk Dil Kurumu) Yeni Baskı, Ankara, 1988, s. 1094.

${ }^{4.3}$ Soyaslan, s.336.
} 
kullanması halinde, söz konusu eylem gerçekleşmiş olur ${ }^{44}$. Bir başka ifade ile, mağdurun herhangi bir sebep dolayısıyla bağlı bulunduğu kimseler tarafından, onun üzerindeki nüfuzlarını kullanmak suretiyle, belirtilen maksatlara ulaşılması halinde nüfuz kötüye kullanılmıştır. Demek ki mağdurun gerek ailevi ve gerekse sözleşme ve sair bă̆ vasıtasıyla jlişkide bulunduğu kimseler tarafından (bunların mağdur üzerinde malik bulundukları nüfuz dolayısıyla) maddede belirtilen fiillerin işlenmiş bulunması halinde, nüfuzun kötüye kullanılması gerçekleşmiş olmaktadır ${ }^{\text {t5 }}$.

Esasında burada söz konusu olan nüfuzun icrası suretiyle fiilin işlenmesidir. Bu nüfuz maddede belirtilen maksatlarla kullanıldığı zaman, zaten kötüye kullanılmış olacaktır. Örneğin bir babanın, çocuğu üzerinde sahip olduğu nüfuz dolayısıyla onu başkasımın emrinde zorla çalışmaya sevk etmesi halinde sözỉ geçen unsur gerçekleşmiş sayılır. Böylece özellikle yoksul kimselerin çocukları üzerindeki nüfuzlarını kullanarak onları çalışmaya yönelik zorlama fiilleri cezalandırılmış olmaktadır. Sözgelimi, bir babanın çocuğunu baskı yoluyla bir başkasının hizmetine vermesi halinde $201 \mathrm{~b}$ maddesi ihlal edilmiş olacaktır. Eger çocuk 18 yaşından küçükse. başkasınm hizmetine verilmesi yeterli olup, baskı yapılmasına dahi gerek bulunmamaktadır. Hiç şüphesiz suçun işlenmesinde nüfuzun kötüye kullanılıp kullanılmadığının belirlenmesi, her somut olayda mahkeme tarafindan belirlenecektir.

Son araç hareket, kişiler iazerindeki denetim olanaklarmdan veya faresizliklerinden yararlanarak rizaların elde etmektir. Esasmda kisiler izerindeki denetim olanaklarım kullammak ile nüfuzun kötüye kullanılması tabirleri arasında yakın bir ilişki vardır. Fakat bu iki deyimden birincisi diğgrine göre daha geniştir. Zira her denetleyenin denetlenen üzerinde nüfuzu bulunmayabilir. İşte bu durumda, yani nüfuzu olmadığı için kullanılmayacağı hallerde, fail bir baskı aracs olarak, denetim olınaklarını belirtilen maksatlara sevketmek için o kimse iizerinde kullanabilecektir. Kişi üzerindeki denetim olanaklarını kullanmak, çok çeşitli ilişkilerden kaynaklanabilir. Ancak her şeyden önce, bu hareketin ictası için, bir denetleyen-denetlenen ilişkisinin bulunması gerekir. Denetleyen-denetlenen ilişkisinin, daha çok, formel bir ilişki olduğu söylenebilir. Öneğin amir ile memur, üst ile ast arasındaki ilişkiler böyledir. Ama ailevi ilişkilerde denetlemeden ziyade nüfuzun kullanılması söz konusudur.

Kişilerin garesizliklerinden yararlanmak ise, herhangi bir sebeple muhtaç durumda bulunan kişilerin bu durumlarının maddede belirtilen maksatlarla sömürülmesi demektir. Bir başka deyişle, mağdurun ekonomik,

\footnotetext{
${ }^{4}$ Önder, Özel Hükümler, s.598.

${ }^{*}$ Dönmezer , s.250
} 
ailevi, sosyal vb. bir sebeple içine düştiuğü kötü durumun istismar edilerek, o kimselerin belirtilen maksatlara yönlendirilmeleri halinde, onların çaresizliklerinden yararlanılmış olunur.

Kanun koyucu kişiler üzerindeki denetim olanaklarından veya çaresizliklerinden yararlanarak bu kimselerin rızalarının elde edilmesinden bahsetmektedir. Kanaatimizce rızanın elde edilmesine yer verilmesi isabetli olmamıştır. Çünkü her iki durumda da mağdurun belirtilen maksatlarla bir yerden başka bir yere götürülmeye veya sevk edilmeye gerçekten rızalarının olduğundan bahsetmek mümkün değildir. Buradaki rıza, maģdurun çaresizliği veya üzerindeki denetim baskısı nedeniyle elde edildiği için, esasen özgür bir irade sonucu verilmiş deÿildir. $\mathrm{Bu}$ nedenle böyle bir ruzanın ayrıca elde edilmesini aramaya gerek yoktur. Sadece kişiler üzerindeki denetim olanaklarından veya çaresizliklerinden yararlanmak suretiyle eylemin icra edilmesini yeterli görmek gerekirdi. Kaldı ki mevcut haliyle bile, bu ibare belirttiğimiz dogrultuda anlaşılmalıdır.

\section{c- Suçun Maddi Unsurunu Oluşturan Assl Hareketler}

Suçun maddi unsurunun gerçekleşmesi için yukarıda belirttiğimiz araç hareketlerin yapılması yeterli deģildir. Bu araç hareketler kullanılmak suretiyle ayrica, failin, mağduru belirtilen maksatlarla tedarik etmesi, kaçırmast, bir yerden başka bir yere götürmesi, sevk etmesi veya barındırmast da gerekmektedir. Şüphesiz suç seçimlik hareketli bir suç olduğundan, bu hareketlerden birisinin yapılması yeterli olacaktır.

Maddede geçen tedarik etme, bulma, sağlama, temin etme, elde etme anlamina gelmektedir ${ }^{46}$. Zorla çalıştırmak veya hizmet ettirmek, esarete veya benzeri uygulamalara tabi kilmak veya vücut organlarının verilmesini sağlamak maksadıyla, bir kimsenin maddede belirtilen araçlarla temin edilmesi halinde suç oluşur. Örneğin belirli bir yerde, failin belirtilen maksatlarla kişileri başkaları için hazır bulundurması ve müracaat eden insanlara bu maksatlarla temin etmesi halinde suç oluşacaktır. Sözgelimi, failin ekonomik stkıntı içerisinde bulunan bir kimsenin, bu durumundan yararlanarak, böbreğini bir başkasına vermesi için hazır olarak tutması halinde, tedarik etme hareketi gerçekleşmiş olur.

Kaçırmak, mağdurun kendi egemenlik alanından çıkarılarak, onun üzerinde frili hakimiyet kuracak şekilde bir yerden başka bir yere

${ }^{40}$ Türkçe Sözlük (TDK), s.l43335. 
nakledilmiş olması demektir ${ }^{47}$. Kaçırmaktan söz edebilmek için mağdurun bulunduğu yerden başka bir yere nakledilmiş olması şartur ${ }^{4 \%}$. Ancak nakledilen yerin mutlaka failin götürmek istediği yer olması gerekmez. Kaçırma unsuru, mağdurun kendi egemenlik alanından çıkarılarak tamamen failin egemenlik alanma girmiş bulunduğu anda tamamlanmış olur ${ }^{\text {th }}$. $\mathrm{O}$ halde fail, cebir, şiddet, baskı, tehdit uygulayarak veya kandırarak zorla çalıştırmak, hizmet ettirmek, esarete tabi kılmak veya vücut organlarını vermesini săglamak maksadıyla mağdur izerinde fiili hakimiyct kuracak şekilde bir yerden başka bir yere naklettiğinde bu unsur gerçekleşmiş olacaktır. Kaçırmadan bahsedebilmek için mağdurun rızasının olmaması gerekir. Bir başka deyişle mağdur. iradesi üzerinde oluşturulan tesirin etkisiyle kaçırılabilir. Bu durum, cebir, şiddet, tehdit, baskı veya kandırma hareketleriyle sağJanabilir. Bunun dışında kalan araç hareketlerin varlı̆̆ı halinde ise kaçırmadan değil, tedarik etme, bir yerden diğer bir yere götürme, sevk etme veya barmdırmadan bahsetmek gerekir.

Bir yerden diğer bir yere götïrmek, failin mağduru kendisi ile beraber bulunduğu yerden başka bir yere götürmesidir ${ }^{\text {st) }}$. Şüphesiz bu götürmenin maddede belirtilen maksatlarla gerçekleşmesi şarttır. Sözgelimi măğdurun cebir veya tehditle bir başkasının hizmetine tabi kılınması için fail ile birlikte belirlenen yere gidilmesi gibi. Suç bir yerden başka bir yere götiurüildüğui anda tamamlanır. Ancak suçun tamamlanması için götürülmek istenilen yere ulaşılması şatt değildir. Önemli olan birlikte mağdurun bulundı ğu yerden hareket edilcrek herhangi başka bir yere gitmektir.

Sevk ctmek ise, maddede belirtilen maksatlarła, bir kimsenin kendi başına bir yerden başka bir yere gönderilmesi demektir ${ }^{\sharp}$. Burada fail mağduru cebir, baskı, tehdit ve diğer irade üzerinde etki eden harekellerle ve maddede belirtilen maksatlara (örneğin vücut organlarmı vermesi için) başka bir yere tek başma göndermektedir. Sevk hareketi mağdurun belirtilen maksatlarla bulunduğ yerden başka bir yere tek başına gönderildiği anda tamamlanır. Kanaatimizce mağdurun tek başına gönderilmesi yeterli olup, istenilen yere ulaşması şart değildir.

$201 \mathrm{~b}$ maddesinde belirtilen son hareket ise barmdrmadir. Maddeye göre, belirtilen maksatlarla ve araç hareketlerden birisini kullanarak mağduru barındıran kişinin eylemi de suç teşkil etmektedir. Barmmak kelinıesi,

\footnotetext{
${ }^{47}$ Dönmezer, s.174; Önder. Özel Hükümler. s.555; Faruk Erem, Ümanist Doktrin Aç1sından Türk Ceza Hukuku Özel Hükümler, C.IV. 3. Baskı, Ankara, 1985, 5.228 . Tezcan/Frdem, s.364: Soyaslan, s.314.

t* Önder, Örel Hükúimler, s.555; Dönmezer, s.174

${ }^{4}$ Dönmezer, s. 175; Önder, Özel Hükümler, s.558.

${ }^{50}$ Dönmezer. s.248; Önder, Özel Hükümler, s.597.

${ }^{\text {s! }}$ Dönmezer, s.248. Önder, Özel Hükümler, s.597.
} 
sözlükte, oturacak, ikamet edecek yer veya imkan bulmak, saklanacak, korunacak yere girmek, anlaşarak uyum halinde yaşamak anlamlarına gelmektedir $^{52}$. O halde bir kimsenin barınmasını sağlamak işini yerine getiren de, barındıran kişi olmaktadır. Bir başka deyişle, bir kimseye oturacak, ikamet edecek, geçimini sağlayacak imkan sağlayan kimse, o kişiyi barındıran kimsedir. $20 \mathrm{lb}$ maddesindeki suçun seçimlik hareketlerinden birisini oluşturan barındırma eylemi de, cebir, şiddet, tehdit, baskı uygulayarak, kandırarak, nüfuzu kötüye kullanarak, çaresiz durumlarından veya denetim yetkisinden yararlanarak bir kimsenin, maddede belirtilen maksatlarla, kısaca geçiminin sağlanması, yani oturma, geceleme, beslenme ve diğer ihtiyaçlarının giderilmesi anlamına gelmektedir. Örneğin fail çaresizliklerinden yararlanarak esaret ve benzeri uygulamalara tabi kılmak için topladığı kimselere bir ev kiralayıp, bu maksadın gerçekleşmesine kadar onların ihtiyaçlarını üstlense, bu kimseleri barındırmış olur. Barındırma hareketi gerçekleştiği anda suç tamamlanır. Kanaatimizce barındırmanın belirli bir müddet sürmesi gerekir. Örneğin bir kimseye bir gün öğle yemeği vermek veya bir gece evinde yatırmak barındırmak anlamına gelmez. O halde barındırma hareketi zorunlu bir mütemadi suç teşkil etmektedir. Bu durumda barındırma temadi edebileceģi için, suç barındırmanın bittiği anda sona erer ve dolayısıyla suçun bitmesine kadar bu suça iştirak etmek mümkün olduğu gibi, mütemadi suça ilişkin diğer hususlar da bu eylem bakımından uygulanma alanı bulur. Örneğin, suç barındırmanın bittiği yerde işlenmiş olur. Yine temadinin bittiği anda yürürlükte olan kanun uygulanır. Davaya temadinin bittigi yer mahkemesi bakar.

\section{2- Manevi Unsur}

İnsan yağması suçunun manevi unsuru kasttır. Taksirle bu suç işlenemez. Ancak kanunumuz belirli maksatlarla bu fiilin işlemesini aradığ için, bu suç ancak özel kastla işlenebilir. Fail amaç ve araç hareketleri, bir kimseyi zorla çalıştırmak veya hizmet ettirmek, esarete veya benzeri uygulamalara tabi kılmak, vücut organlarının verilmesini sağlamak maksadıyla yapmahıdır. Bu maksatlardan herhangi birisiyle hareket etmeyen, yani araç ve amaç hareketleri bu maksatlardan biri için yapmayan failin eylemi bu suçu oluşturmaz. Fail başka maksatlarla hareket ediyorsa, örneğin şehvet hissi veya fuhuş gibi, bu durumda kanunumuzun sekizinci babının 2 ve 3. fasıllarında yer alan kız, kadın ve erkek kaçırmak veya kadın ticareti suçları işlenmiş olur. Demek ki failin maksadı, bu tür suçları birbirinden ayırmaktadır.

\footnotetext{
${ }^{52}$ Büyük Türkçe Sözlük, s.ł11; Türkçe Sözlük, s.143.
} 
Ancak failin cezalandırılabilmesi için bu maksatlarla maddi unsuru oluşturan eylemlerde bulunması yeterli olup, aynıca maksada ulaşılması gerekmez. Görüldü̈gü gibi $201 \mathrm{~b}$ maddesinde, insanı alçaltan, insan haysiyetini ortadan kaldırarak onu bir obje konumuna indirgeyen maksatlarla eylemi gerçekleştiren fail cezalandırılmaktadır.

Ayrıca fail bu maksatlarla bir kimseyi kendisi için tedarik edebileceği gibi, bir başkası için de bunu yapabilir. Başkası için belirtilen maksatlarla mağduru tedarik etmesi durumunda, fail bu suçta bir aracilık görevi yapmış olacaktır. Bu ihtimalde şayet üçüncü kişinin bu fiilin yapılmasına iştiraki söz konusu değilse, onun bakımından bu suç oluşmaz.

\section{a- Zorla Çalış̧ırmak veya Hizmet Ettirmek}

Zorla çalșsturmak, bir kimsenin, cebir veya tehdit altında bedensel bir uğraşta bulundurulması anlamına gelir. Örneğin bir kimsenin zorla taş ocağında çalı̧̧ırıııması maksadıyla kaçırılması gibi. Hizmet ettirmek ise zorla çalıştırmaya göre daha geniş bir kavram olup, yine bir kimsenin cebir veya tehdit altında emre hazır bir şekilde bulundurulması demektir. Bu itibarla, bedensel olarak yapılacak uğraşlardan başka, bir kimsenin arzusu hilafına diğerinin herhangi bir ihtiyacını temin etmek maksadıyla kaçırılması halinde de suç oluşur.

\section{b- Esarete veya Benzeri Uygulamalara Tabi Kılmak}

Esaret, sözlükte, kölelik, tutsaklık, esirlik, boyunduruk anlamına gelmektedir ${ }^{\text {33 }}$. Esarete tabi kılmak, bir kimsenin tutsak, köle veya esir olarak tutulması demektir. Kanunumuz suçun işlenme alanını geniş tutmak için. kölelik, esirlik ve benzeri uygulamalara tabi tutmak maksadmı da maddede belirtmiştir. Benzeri uygulamalara tabi kılmaktan maksat, esarete benzeyen. yani bir kimsenin kişiliği üzerinde fiziksel hakimiyet kurmayı doğuran her hangi bir durumda bulundurmaktır. Esaret veya benzeri uygulamalara tabi kılınan kişi, tabi olunan şahsın emri altında bulunmakta ve özgür iradesi ile kaderini yönlendirememektedir. Bir başka deyişle, irade özgürlüư̆ünün tümüyle ortadan kaldırılarak, kişinin tamamen başkasının arzu ve isteklerine tabi kılınması halinde bu maksat gerçekleşir. Şahıs başkasının elinde adeta bir alettir ve kendi istekleriyle herhangi bir tercihte bulunması mümkün değ̣ildir.

\footnotetext{
${ }^{53}$ Türkçe Sözllǜ . s.465.
} 


\section{c- Vücut Organlarının Verilmesini Sağlamak}

Bu maksat diğerlerine göre daha somut bir durumu ifade etmektedir. Bir kimsenin organlarının verilmesini sağlamak maksadıyla maddede belirtilen eylemlerin yapılması halinde de suç gerçekleşecektir. Örnȩ̧in bir kimsenin böbreğini vermesi maksadiyla cebir veya tehdit ya da baskıyla veya nüfuzunu kullanarak başka bir yere nakledilmesi halinde eylem tamamlanacaktır. Vücut organlarını vermesi maksadıyla maddede belirtilen eylemlere maruz kalan kimsenin, diğerlerinde olduğu gibi, yaşayan bir kimse olması gerekir. Bir başka ifade ile, henüz ölmüş bir kimsenin vücut organlarının verilmesini sağlamak maksadıyla yakınları üzerinde cebir veya tehdide başvurarak cesedi kaçıran kimsenin eylemi bu suçu oluşturmaz. $\mathrm{Bu}$ ihtimalde, cesedin hukuki niteliğine göre çeşitli ihtimaller ortaya çıar. Kanaatimizce de, hukuka aykırı olarak ve yeni öImüş bir insan cesedinden elde edilen organlara verilen astronomik fiyatlar gözönünde tutulduğunda cesedin de bir eşya olarak kabul edilmesi mümkün olduğu içinn ${ }^{4}$, bu ihtimalde yağma (TCK m.495) suçu düşünülebilir.

Ayrıca tekrar belirtelim ki, suçun oluşması için bu ve diğer maksatlarla failin suçun icra hareketlerinde bulunması yeterli olup, bu maksatların gerçekleşmesi şart değildir.

\section{3- Hukuka Aykırılık Unsuru}

\section{a- Genel Olarak}

Hukuka aykırılık unsuru denildiğinde,bundan tipik eylemin tüm hukuk düzeni ile çelişme ve çatışma halinde bulunması anlaşılır ${ }^{55}$. Şayet bir eylemin yapılmasına herhangi bir hukuk kuralı izin veriyorsa, o eylem hukuka uygun olacaktır. İşte hukuka aykırılık unsurunu ortadan kaldıran, fiili ceza kuralının amacına aykırı bir hale getirmeyen, fiilin dogrudan hukuka uygun bir şekilde dogmasını saglayan sebeplere hukuka uygunluk sebepleri denmektedir ${ }^{56}$.

Insan yağması suçu bakımından herhangi bir hukuka uygunluk sebebinin gerçekleşmesi zor gözüikmektedir. Öncelikle böyle bir eylemin yapılmasında meşru müdafaanın gerçekleşmesi (TCK m.49/2) mümkün olamaz. Bir başka ifade ile, bir kimse kişiliğine yönelik bir saldırıya karşı kendisini savunmak için, saldırana karşı 201 b maddesini ihlal etme

\footnotetext{
${ }^{54}$ Artuk/Gökcen/Yenidünya, Özel Hükümler, s.345, dn.78.

ss Sulhi Dönmezer/Sahir Erman, Nazari ve Tatbiki Ceza Hukuku, Genel Kısım, C.II, 12. Bast, İstanbul. 1999, s.1-2; Centel. s.222.

${ }^{56}$ Dönmezer/Erman. C.II, s.18.
} 
mecburiyetinde kalamaz. Belki ıztırar hali (TCK m.49/3) gerçekleşebilir. Sözgelimi, bir kimse, organ naklinin gerçekleşmemesi halinde ölebilecek olan bir yakınını kurtarmak için, diger bir kimseyi bu maksatla cebir veya tehditle kaçırsa veya kandırarak götürse, şartları oluşmuşsa, ıztırar halinin varlığından söz edilebilir.

Zorla çalıştırmak veya hizmet ettirmek maksadı bakımından mahkum veya tutukluların durumu. kanun hükmünün icrası (TCK 49/1) hukuka uygunluk sebebini oluşturabilir. Arıcak bu durumda dahi, yapılan muamele insan haysiyetini, kişiliğini ihlal ediyorsa eylem hukuka uygunluk smırını aşacaktır. Aynı değerlendirme askerlik hizmetinde bulunan erler bakımından da geçerlidir.

Bu suç bakımından ceza kanunumuzda yer almayan hukuka uygunluk sebeplerinden mağdurun nizası ïzerinde ayrıca durmak gerekir. Zira maddenin ikinci fıkrasında mağdurun rızası ayrıca düzenlenmiştir.

\section{b- Mağdurun Rızası}

201b. maddenin ikinci fikrasinda "Birinci fikrada belirtilen amaģlarla girişilen ve sıఢ̧u oluşturan eylemter var olduğu takdirde, mağdurm rızast yok sayılı" şeklinde bir hüküm yer almaktadır. Bu fikranın gerekçesinde "Maddenin ikinci fıkrasında, belirtilen amaçları elde etmek izzere girişilen ve suçu oluşturan yardımcı eylemler varsa artık, mağdurun rızasınn yok sayılacağı belirtilmiştir. Örneğin bir kimsenin organlarını vermek hususundaki rızası, yukarıda belirtilen eylemler sonucunda elde edilmişs ise, suçun oluşması bakımından bu rıza yok sayılacaktır" denilmektedir ${ }^{5 ?}$.

İkinci f $\mathrm{k}$ kranın metni ile gerekçe arasında tam bir uyumun olmadı̆̆ görülmektedir. Madde metninde suçu oluşturan evlemlerden bahsedildiği halde, gerekçede yardimtc evlemler ifadesi geçmektedir. Ancak nasıl anlaşılırsa anlaşılsın böyle bir fıkranın lüzumsuz veya fazladan olduğunu düşünmekteyiz. Bunun iki nedeni vardır. Birincisi şayet bu hüküm ile, bu suç bakımından mağdurun rızasının bir hukuka uygunluk sebebi oluşturmayacağı kastediliyorsa, esasen buna gerek yoktur. Çünküi suçun koruduğu hukuksal değer olan irade özgürlüğ̈̈̈nden feragak, esasen rızanın geçerli olmadığı bir alandır. Zira hiç kimse özgürlüklerinden vazgeçemez veya onları hukuka ya da ahlaka aykırı olarak smırlayamaz (MK, m.23/2) ${ }^{58}$. Medeni Kanunun bu hükmü ile, kişinin özgürlügünden vazgeçmesine veya özgürliugüinün hukuka ya da ahlaka aykırı olarak sınırlandırılmasına rıza gösteremeyeceği açıkça belirtildiğinden, 201b maddesinde belirtilen

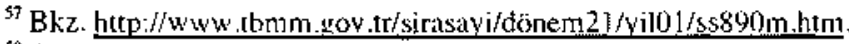

${ }^{s *}$ Dönmezer/Erman. II, s.76. 
maksatlarla maddi ve manevi varlığının sömürülmesine bir kimsenin rıza göstermesinin hukuksal bir değeri bulunmamaktadır. Zira bir kimsenin, iradesi üzerinde baskı oluşturan araçlar kullanılsın veya kullanılmasın, zorla çalıştırılmaya veya hizmet etmeye, esarete veya benzeri uygulamalara tabi olmaya ve vücut organlarının verilmesine rıza göstermeye hakkı bulunmamak gerekir ${ }^{59}$.

Diğer taraftan, hem bir kimsenin maddede belirtilen maksatlarla kendisine karşı tehdit, baskı, cebir veya şiddet uygulanmasından, bir başkasının kendisi üzerindeki nüfuzunu kötüye kullanmasından, kandırılmasından veya kendisi üzerindeki denetim olanaklarından veya çaresizliklerinden yararlanılarak rızasının elde edilmesinden bahsetmek ve hem de mağdurun bu maksatlarla üzerinde uygulanan bu araç hareketlere rıza gösterebileceğinden bahisle bu rızasının geçersiz olduğunu söylemek mantıksızdır. Yani baskı araçları ile zaten ortadan kaldırılan bir rızanın geçerli olmadığını söylemek gibi gereksiz bir durum ortaya çıkmaktadır. Çünkü bu hareketler varsa zaten mağdurun rızası yoktur. Zira mağdurun rızasını bir hukuka uygunluk sebebi oluşturabilmesi için, rıza açıklamasının hata, aldatma, tehdit, cebir gibi iradeyi bozucu etkiler altında yapılmamıs olması gerekir ${ }^{6 t}$. Dolayısıyla fikranın gerekçesinde verilen örnekte olduğu gibi, bir kimsenin organların vermek hususundaki rızasının, maddede belirtilen eylemler sonucu elde edilmesi halinde, bu rızanın yok sayılacağının belirtilmesine gerek yoktur. Zira ortada gerçekten özgür irade ile verilmiş bir rıza olmadığı için, olmayan bir şeyin olmadı̆̆ını belirtmek lüzumsuz olmaktadır.

Eğer fıkrada geçen "suçu oluşturan eylemler"den maksat, tehdit, baski, cebir veya şiddet, kandırma şeklindeki araç hareketlerin dişında kalan asıl hareketler ise (ki gerekçede bu ibarenin araç hareketler anlamına geldiği açıklanmaktadır), yani mağdura karşı araç hareketlere başvurulmaksızın onun belirtilen maksatlarla kaçırılması veya başka bir yere götürüilmesine rıza göstermesimin geçersiz olacağı anlatılmak isteniyorsa, o zaman da üçüncü fıkra anlamsız hale gelmiş olacaktır. Çünkü bu fıkrada 18 yaşını doldurmamış olanların zorla çalıştırılmak veya hizmet ettirmek, esarete veya buna benzer uygulamalara tabi kılmak veya vücut organlarını vermesini sağlamak için, maddede belirtilen araç hareketlerden herhangi birisine başvurulmaksızın, kaçırılmaları, bir başka yere götürülmeleri veya sevk edilmeleri ile suçun oluşacağı belirtilmiştir.

\footnotetext{
${ }^{\text {H }}$ Artuk/Gökcen/Xenidünya, Gene] Hiküimler J, s.501.

to İçel/Sokullu-Akıncı/Özgenç/Sözüer/Mahmutoğlu/Ünver, s.185; Dönmezer/Erman. II, s. 72 .
} 
Bu durumda ikinci fikradan ancak şöyle bir anlam çıkarılabilir. Şayet 18 yaşından büyük olan bir kimse, maddede belirtilen araç hareketlere başvuruimaksızın, sözgelimi esarete veya buna benzer bir duruma tabi olmaya riza göstererek bir yere götüriilürse, eylem hukuka uygun olacaktır. Zaten 18 yaşını doldurmuş olan bir kimsenin araç hareketler kullanılmaksızın maddede belirtilen maksatlarla kaçırılması veya tedarik edilmesi, birinci fikra bakımından tipik olmadı̆̆ından, suçu oluşturmayacaktır. Demek ki bu hüküm fazladan bir hükümdür ve maddeden çıkartılması daha yerinde olacaktır.

\section{V- SUÇUN ÖZEL GÖRÜNÜŞ ŞEKILLERI}

\section{1- Suçun Tamamlanması ve Teşebbüs}

Insan yağması suçu, maddede belirtilen maksatlarla, cebir, şiddet, baskı, tehdit, kandırma, nüfuzu kötüye kullanma, kişiler üzerindeki denetim olanaklarından veya çaresizliklerinden yararlanmak suretiyle bir kimsenin tedarik edilmesi, kaçırılması, bir yerden başka bir yere götürülmesi, sevk edilmesi veya barındrrması ile birlikte tamamlanır. Demek ki tedarik etme, kaçırma, bir yerden başka bir yere götürme, sevk etme veya barındırma hareketlerinin belirli nitelikte olması gerekmekte ve bu hareketlerin yapılması ile birlikte de suç tamamlanmaktadır. Daha önce de belirttiğimiz gibi, bu suç hareketin yapılması ile birlikte tamamlandığı, hareketin yapılmasından başka bir neticenin gerçekleşmesi aranmadığı için, şekli bir suçctur. Bu itibarla da bu suça tam teşebbuis olanaksızdır, fakat eksik teşebbüs mümkündür. Sözgelimi fail, araç hareketlere başvurmasma rağmen belirtilen maksatlarla mağduru kaçıramamış veya tedarik edememiş olabilir. Ayıı şekilde fail suçun diğer icra hareketlerini (bir yerden diğer yere götürme veya sevk veya barındırma) de elinde olmayan sebeplerle bitirememiş olabilir. Demek ki failin irade üzerinde etkisini gösteren zorlama hareketlerine başvurması ile birlikte suçun icra hareketleri başlamakta ve bunun sonucu olarak da mağduru tedarik ettiği, kaçırdığı, sevk ettiği, bir yerden başka yer götürdüğ̈i veya barındırdığ bitmekte ve suç tamamlanmaktadır.

Yine ifade ettiğimiz gibi, bu suç tipinin diğer bir özelliği mütemadi bir suç olmasıdır. Bilindiği gibi bu tip suçlarda hareketten doğan netice belirli bir süre devam etmektedir ${ }^{6}$. Bu durumda insan yağması suçunda suçun tamamlanması ile bitmesi farklı zamanlarda gerçekleşecektir. Suçun maddi unsurunu oluşturan asıl hareketler, hürriyeti tahdidin özel işleniş̧ şekillerini

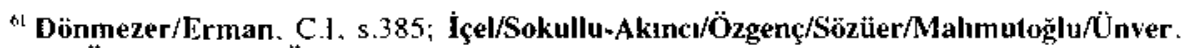
s.69; Öztürk/Erdem/Özbek. Uygulamalk Ceza Hukuku. s.137; Artuk/Gökcen/Yenidünya. Genel Hüküimler I, s.447; Centel. s.200; Demirbaş. s.204.
} 
oluşturmaktadır. Sevk, tedarik, kaçırma, barındırma ve bir yerden başka bir yere götürme hareketlerine, iradeyi etkileyen zorlayıcı hareketler vasitasıyla ulaşılması gerektiği için, mağdurun aynı zamanda hareket özgürlüğii ortadan kaldırılmakta ve bu durum sona erinceye kadar da, suç işlenmeye devam etmektedir. Sözgelimi kaçırma hareketi, failin mağdur üzerinde fiili hakimiyet kurması ile birlikte tamamlanır, fakat bitmez. Kaçırılan kişinin özgürlüğüne kavuştuğu anda kaçırma sona erer. Aynı şekilde bir yerden başka bir yere götürme, sevk etme, barındırma ve tedarik etme hareketleri de temadi edebilir. Bu itibarla bir yerden başka bir yere götiirme ve sevk etme, bu hareketler yaptldığı anda tamamlanır ve fakat failin mağdur üzerindeki baskısı sona erinceye kadar devam eder.

\section{2- Iç̧ima}

Bu suç, kanunumuzun 179 ve 188. maddelerinde düzenlenen hürriyeti tahdit ve cebir kullanma suçlarına göre özel hüküm niteliğindedir. Dolayısıyla bu suçlar arasında bir görünüşte içtima ${ }^{62}$ durumu söz konusu olduğu için, diğer maddeler gerçekte ihlal edilmiş değildir. Bu nedenle fail, tek ihlalden dolayı, yani yalnızca 201b maddesine göre cezalandırılır. Fail hakkında ayrıca 179 ve 188. maddeler uygulanmaz. Çünkü gerçekte ihlal edilen tek bir hüküm vardır, o da $201 \mathrm{~b}$ maddesidir.

Daha önce de belirttiğimiz gibi bu suçun oluşması için failin belirli maksatlarla maddi unsuru oluşturan hareketleri yapması yeterli olup, ayrıca failin maksadına ulaşması gerekmez. Ancak suçta belirtilen maksat da gerçekleşmiş ise nasıl hareket etmek gerekecektir? Sözgelimi fail, vücut organlarını vermesi için cebir veya tehditle kaçırdığı mağdurun vücut organlarının gerçekten verilmesini sağlamışsa içtima problemi nasıl çözümlenecektir?

Esasında yasa koyucu, failin maksadına ulaşmasını suçun bir ağırlatıcı sebebi olarak kabul etmeliydi. Nitekim kanunumuzda bu tip bölïnebilen suçlara $^{63}$ yer verilmiştir (örneğin TCK m.188, 192, 499 gibi). Böyle bir düzenleme $201 \mathrm{~b}$ maddesinde bulunmadiğına göre, kanaatimizce, bu ihtimalde suçların içtimaını gerektiren bir durum olmadığı için, failin maksadını oluşturan eylemlerin gerçekleşmiş olması ayrıca suç teşkil ediyorsa, cezalar içtima ettirilmelidir. Sözgelimi organın verilmesi de sağlanmışsa ve bu durum Organ ve Doku Alınması, Saklanması ve Nakli Hakkında Kanunun ${ }^{64} 15$. maddesine aykırılık oluş̧uruyorsa, failin hem bu suçtan hem de $201 \mathrm{~b}$ maddesinden dolayı ayrı ayrı cezalandırılması

\footnotetext{
${ }^{62}$ Bkz. Kayıhan Içel, Suçların Içctimaı, İstanbul, 1972, s.167 vd.

${ }^{63}$ Kavram hakkında bkz. Ayhan Önder, Ceza Hukuku Genel Hükümler, C.II-III, İstanbul, 1992. 60 vd.; Artuk/Gökcen/Yenidünya, Genel Hiikümler I, s.434-435.

${ }^{6}$ Kanun No:2238. RG.3.6.1979, sy.16655.
} 
gerekecektir. Sözï geçen kanunun 15. maddesinde "Bu kanuna aykırı şekilde organ ve doku alan, saklayan, aşllayan ve nakledenlerle bunların alım ve satımını yapanlar, alım ve satımına aracilik edenler veya bunun komisyonculuğunu yapanlar hakkında, fiil daha ă̆ır bir cezayı gerektirmediği takdirde iki yıldan dört yıla kadar hapis ve 50.000 liradan 100.000 liraya kadar ağır para cezasına hükmolunur" denilmektedir. $201 \mathrm{~b}$ madde ile 15. madde arasında asli-tali norm ilişkisi söz konusu olmadı ğından unsurlarının gerçekleşmesi halinde her iki maddede ihlal edilmiş olur. \$̧ayet unsurları oluşmadığı için 15. maddeye göre failin cezalandırılmásı mümküun değilse, bu durumda eylem müessir fiil suçunu (TCK m.456) oluşturacaktır.

Vücut organlarının verilmesini sağlamak maksadı bakımındaı bu şekilde bir çözüm yolu düşünülebilirse de, aynı durum diğer maksatların gerçekleşmesi halinde geçerli olmayacaktır. Gerçekten fail iradeyi zorkayan araçlarla bir kimseyi zorla çalıştırmak veya hizmet ettirmek ya da esarete veya benzeri uygulamalara tabi kılmak için kaçırsa ve bu maksadını kaçırdığı mă̆dur üzerinde gerçekleştirse, $20 \mathrm{lb}$ maddesindeki suç hala işlenmeye devam edecektir. Burada özgürliağün kısıtlanması mütemå̉i bir suç teşkil ettiğ için, maksada ulaşmak eylemi ayrı bî suçu oluşturmayacaktır. Vǚcut organlarınm verilmesi için kaçırılan kişiden ayrıca organın alınmasında ise, mağdurun özgürlügüüün kısıtlanmasından başka, bu özgürlük kisıllaması devam ederken ikinci bir hareket daha yaptlmakta ve organın ahmması özgürlük hukuksal değerinden başkaca değerleri koruduğu için bağımsız bir suça sebebiyet vermektedir. Bu nedenle zorla çălıştırmak veya hizmet ettirmek ya da esarete veya benzeri uygulamalara tabi kılarak maksadını gerçekleştiren fail, yalnızca $201 \mathrm{~b}$ maddesinden dolayı cezalandırlacaktır. Kanaatimizce $201 \mathrm{~b}$ maddesine, failin maksidna ulaşması halinde cezanın arttırlacağına ilişkin bir fikranın ekłenmesi gerekir. Meveut haliyle, farklı maksatlar aynı maddede zikredikliy̆i için, adil olmayan sonuçlaıra götürmektedir.

İçima konusunda çözümü gereken diğer bir husus da, kullanılan cebir ve şiddetin aynı zamanda müessir fiil suçunu (TCK m.456) oluşturması durumunda ortaya çıkmaktadır. Cebir ve şiddetin unsur veya ağırlatıcı sebep olduğu suçlarda, bu suçların işlenmesi için zorunlu olan smırı aşan cebirin aynca müessir fiil suçunu teşkil edeceği ve fail hakkında cezalarm içtima ettirileceği görüşü, genelde, benimssenmektedir ${ }^{65}$. Fakat bir fiil ne zaman cebir ve şiddetin smurını aşarak miiessir fiil teşkil edecektir? Kanunumuzda bu soruya cevap oluşturacak bir dïzenleme yoktur. Doktrindeki fikirler ise değişiktir. Örneğin kanunumuzun 174. maddesindeki siyasi hakların

6í Erman/Özek (Sahir Erman), Ceza Hukuku Özel Bölüm, Kişilere Karşı İșlenten Suçiar. İstanbul, 1994, s.130; Önder, Özcl Hükümler, s.35; Artuk/Gökcen/Yenidünya. Ö/eI Hükümler. s.576; Soyaslan. s.97; Çetin Arslan. "Memura Aktif Mukavemet Suçu". YD. C.28, Ekim 2002 sy.4. s.494 495. 
kullanılmasını engelleme suçunda unsur, 179/2. maddesindeki hürriyeti tahdit suçunda ise ağırlatıcı sebep teşkil eden cebir ve şiddeti açıklarken konuya değinen Artuk/Gökcen/Yenidünya'ya göre, kişilere karşı kullanılan şiddetin basit müessir fiil (TCK m. 456/1) sınırını aşmaması gerekir. Yazarlara göre, siyasi hakların engellenmesi kastıyla, suçun oluşumu için zorunlu olan dereceden daha fazla şiddet kullanılmışsa, her iki suç (siyasi hakların kullanılmasını engelleme ve şiddet sonucu gerçekleşen müessir fiil suçları, TCK m.456/2-3) gerçek içtima kurallarına göre birleştirilmeli veya şartları varsa fikri içtima kuralı uygulanmalıdır ${ }^{66}$. Demek ki bu yazarlara göre, 456. maddenin 1 ve 2 . fıkralarını ihlal eden cebir ve şiddet suçun unsurunu oluşturmakta, bunun dışındakiler ise şartları varsa fikri içtima, yokșa gerçek içtima kurallarına göre değerlendirilmektedir ${ }^{67}$.

Erman ise, gaye suçun işlenmesi açısından zorunlu olan suntrlar içerisinde kalan müessir fiilin, cebir ve şiddeti oluşturacă̆ı, bunun ötesine geçen müessir fiillerin ise ne mürekkep suç ne de fikri içtima kurallarına göre tek suç sayılmasının mümkün olmadığı ve dolayısıyla failin müessir fiilden ayrıca cezalandırılması gerektiği görüșündedir ${ }^{68}$. Ancak yazar, 456. maddedeki hangi düzeyde müessir fiilin zorunlu sınırlar içerisinde kalacağı hakkmda bir görüş belirtmemektedir. Tezcan/Erdem ise cebir kullanma (TCK m.188) suçunu incelerlerken, kullanılan cebrin müessir fiil boyutuna ulaşması halinde fikri içtima kuralları gereğince failin en ağır cezayı gerektiren suçtan dolayı cezalandırılması gerektiğini belirtirlerken ${ }^{69}$, yağma suçunda (TCK m.495) unsur olan cebir ve şiddetin müessir fiil düzeyine ulaşması halinde ise, failin bu suçtan dolayı da ayrıca cezalandırılması gerektiğini ifade etmektedirler ${ }^{70}$. Soyaslan ise, $456 / 4$. maddede yer alan hafif müessir fiillerin cebre dahil olduğu, bunu aşan cebrin ise ayrıca müessir fiil suçunu oluşturacağı görüşsündediri"

Yargıtay ise, tartışılan konuya ilişkin olarak, istikrarlı bir görüş oluşturamamıştır. Sözgelimi memura aktif mukavemet suçunda (TCK m.258) unsur olan cebir ve şiddetin, memurun 15 gün (TCK m.456/1) ve hatta 20 gün veya daha fazla (TCK m.456/2) mutat iştigaline devam edememesi sonucunu doğurması halinde fikri içtima (TCK m.79) kuralını uygulayarak failin yalnızca m. $456 / 1$ veya 2 'den dolayı cezalandırılması gerektiğini belirtmektedir ${ }^{72}$. Yüksek Mahkeme yakın tarihte vermiş olduğu

\footnotetext{
th Artuk/Gökcen/Yenidünya, Özel Hükümler, s.61.

${ }^{67}$ Artuk/Gökcen/Yenidünya, Özel Hükümler, s.156.

t* Erman/Özek. s.130.

*) Tezcan/Erdem, s.49.

Tezcan/Erdem. S.544.

${ }^{71}$ Soyaslan, s.97-98.

72 Y. 4.CD, 15.4.1993, 1326/3118; Y. 1.CD, 26.10.1978, 3789/3736; Y. 4.CD, 4.10.1983, $4134 / 4589$ (bu kararlar için bkz. Arslan, s.595, dn.89.90.91).
} 
bir kararında ise, sanığın yönelttiği cebir ve şiddetin ayrı bir müessir fiil suçunu oluşturduğunun kabul edilebilmesi için, mağdurun bu eylem nedeniyle săğlığının bozulması, akli melekelerinde karışıklık oluşması veya cismen eza duyması gerektiğini belirterek, müessir fiilin en hafif derecesinin dahi (TCK m.456/4) cebir ve şiddet unsurunun dışında kalacağı ve ayrı bir suç oluşturacağı sonucuna varmışır. Bu kararında mahkeme, TCK m.269 çerçevesinde kalan cebir ve şiddetin 3 gün süreyle mutat iştigalden mahrumiyeti kapsamayacağını belirterek, failin $456 / 4$ 'den dolayı ayrıca cezalandirılması gerektiğine karar vermiştir ${ }^{73}$.

Kanaatimizce cebir ve şiddetin unsur veya ağırlatıcı sebep olarak yer aldığı suçlarda, asıl suçun işlenmesi için zorunlu olan sıntrları aşmayan müessir fiillerin cebre dahil olduğı ve bu sınırı aşanların ise ayrıca müessir fiili oluşturacağı yönündeki görüş kabu] edilemez. Çünkü zorunlu olan sintrin nasıl ve neye göre belirleneceği konusunda bilimsel ve objektif bir ölçüt geliştirilemez. Bu durumdá fikri içtima kuralından hareket etmek zorunludur. Bu itibarla ortada aynı kasıtla ve tek fiille kanınun çeşitli hiikümleri ihlal ediliyorsa (TCK m.79) faile en ağır suçun cezası verilecektir. Şayet failin eylemini aynı kasıtla yapmadı̆̆ sonucuna varılırsa, müessir fiilin derecesi ne olursa olsun, iki ayrı suçun cezalarımın içtima ettirilmesi gerekir.

Diğer taraftan bu suç şartlarını taşıması halinde müteselsil suç ç $^{74}$ şeklinde de işlenebilir. Ayrıca örneğin kaçırma hadisesi konuta veya eklentisine girilerek işlenmişse, faile konut dokunulmazlığından dolayı ayrıca ceza vermek gerekir. Çünkü bu durum suçun unsuru veya ağırlatıcı sebebi olmadığı gibi (TCK m.78), fikri içtima (TCK m.79) hali de söz konusu değildir.

\section{3- İştirak}

İştirak bakımından bu suç bir özellik arz etmez. Bu itibarla iş̧irakin her şekli ile suça katılmak mümkündür (TCK m.64, 65). Ancak suçun mütemadi bir suç olması nedeniyle, iştirak konusunda ortaya çıkan özelliğin gözönünde tutulması gerekir. Bilindiği gibi mütemadi suçların, neticenin gerçekleşmesiyle tamamlanan ve biten ani suçlardan en önemli farkı, suç işlenmeye devam ettiği sürece bu suça iştirakin mümkün olmasıdır ${ }^{75}$. O halde insan yağması suçunun tamamlanması ile bitmesi arasındaki zaman dilimi içerisinde de bu suça iştirak edilebilecektir. Sözgelimi maddede belirtilen maksatlarla mağdurun kaçırıldığını ögrenen kişinin bu eyleme

\footnotetext{
${ }^{7}$ Y.CGK, 19.6.2001, E.2001/4-128, K.2001/130 (YKD, C.27, Aralık 2001, sy.12. s.1870 $\mathrm{vd}$.).

${ }^{74}$ Bkz. Türkan Yalçın Sancar, Müteselsil Suç, Ankara, 1995, s.19 vd.

${ }^{75}$ İçel/Sokullu-Akıncı/Özgenç/Sözïier/Mahmutoğlu/Ünver. s.70.
} 
yardım etmesi halinde (örneğin otomobilini tahsis etmesi) TCK m. 296'dan değil, iştiraki çerçevesinde bu suçtan dolayı sorumluluğu söz konusu olacaktır ${ }^{76}$. Ayrıca suçun iki hareketli olması nedeniyle suçun araç hareketlerini faillerden birinin, asıl hareketi ise bir başkasının gerçekleştirmesi mümkündür. Bu durumda her iki fail de suçu irtikap eden olarak nitelendirilecektir. Sözgelimi faillerden birisi cebir ve şiddet uygulayarak mağduru bayıltsa veya uyuşturucu ya da uyku hapı gibi ilaçlarla etkisiz hale getirse, diğeri de bu hale getirilen kişiyi kaçırsa, her ikisi de suçu irtikap ettiği için suçun asli maddi faili olacaklardır (TCK m.64/1).

\section{VI- SUÇU ETKILLYEN HALLER}

Incelediğımiz suçta kanun tek bir ağırlatıcı sebep kabul etmiş, bunun dışında ayrica herhangi bir ağırlatıcı veya hafifletici sebebe yer vermemiştir. 201b. maddenin son fıkrasına göre "Yukarıdaki fıkralarda yazılı suçlar örgütlü olarak işlendiği takdirde faillere verilecek cezalar bir kat artırılarak" hükmolunacaktır. Bu durumda insan yă̆ması suçu örgütlii olarak işlendiği takdirde suçun cezası artırılacaktır. O halde bu ağırlatıcı sebebin uygulanabilmesi için, suçun ne zaman örgütlü olarak işlendiğinin belirlenmesi gerekecektir.

Bir suçun örgütlï, teşekkül halinde işlendiğinden bahsedebilmek için, o suçun, belli amaç etrafında suç işlemek üzere devamlı surette fiilen birleşmiş en az iki kişi tarafından işlenmesi gerekir. Böyle bir birleşme, teşekkül, soyut birleşme olmayıp, emir-komuta zincirinin hakim olduğu, disiplinli hiyerarşik bir yapılanmayı ifade eder ${ }^{77}$. Suç teşekkülünün amaçlanan suçları işlemede sağladığı kolaylık, hem nicelik, hem de nitelik itibariyledir. Gerçekten amaçlanan suçları işlemede ihtiyaç duyulan eleman ve malzeme örgüt sayesinde kolaylıkla temin edilebildiği gibi, diger taraftan da teşekkül içinde bir araya gelen kişiler, dayanışma içinde oldukları için, amaçlanan suçları işlemekte tereddüt etmeyip, korkusuzca hareket edebilmektedirler ${ }^{78}$. Işte suçun örgütlü olarak işlenmesinin ağırlatıcı sebep sayılmasının nedeni, örgütün suçun işlenmeșinde sağladığı bu kolaylık nedeniyledir.

\footnotetext{
Th Yargıtay da, kanunumuzun sekizinci babının ikinci faslında düzenlenen "kız ve kadın ve erkek kaçırmak" cürümierinde, kaçırmanın mütemadi karakteri nedeniyle aynı yönde kararlar vermekteđir: "Temadi devam ederken bu suça iştirak mümkündür. Evinde birkaç gün kalma halinde 65. madde uygulałır" (Y. 4. CD. 3.6.1952, 5973/5973); "Sanığın dağda hayvan otlatan mağdureyi silah tehdidi ile kaçınp iki gün kaldıktan sonta, yerlerinin öğrenilmesini müteakip, sanığı takipten kurtarmak ve Ankara'ya göndermek için babasının Jeep kiralaması ve sanığt bu amaçla Ayancık'a getirmesi mütemadi olan bu suça iştiraktir" (Y. 5.CD. 22.9.1981, 2684/2739); "Bu gibi durumda TCK. nun 296/1 maddesi ile hủküm kurulamaz" (Y. SCD. 18.9.1979.2516/2414) (kararjar için bkz. Önder. Özel Hưkümler, s.553).

${ }^{\pi}$ Özgenç/Sahin, s.464, 467.

${ }^{78}$ Özgenç/Şahin, s.464.
} 
Bu durumda sadece 201 b maddesinde belirtilen suçu belirli bir kişiye karşı işlemek için bir araya gelen kişiler bu suçu örgütliu olarak değil, iştirak halinde işlemiş olacaklardır. Fakat bu kişiler belirsiz kimselere karşı bu suçu işlemek için teşekkül oluştursalar ve bu doğrultuda belirli bir kimseye karşı $201 \mathrm{~b}$ maddesindeki eylemi gerçekleştirseler, bu durumda ağırlatıcı sebep gerçekleşmiş olur. Sözgelimi "organ mafia"sı olarak teşekkül eden bir örgüt, bir kimseyi organını vermesi için cebir kullanarak kaçırsa, 201b maddesinin nitelikli hali gerçekleşmiş olur. Böyle bir durumda fajllerin hem $20 \mathrm{lb} / \mathrm{son}$ maddesinden, hem de 313. maddeden dolayı gerçek içtima kuralarına göre cezalandırılması gerekecektir. Bir başka ifade ilc, örgütün maksadı doğrultusunda suç işlemesi halinde faillere her iki suçun da cezast verilecektir ${ }^{74}$.

Yukarıda değgişik vesilelerle değindiğimiz gibi, bu suçun ağırlatıcı sebebi bakımından maddede yer alan düzenleme yetersizdir. Kanaatimizce suçun 12 yaşından küçüklere karşı araç hareketlere başvurulmaksızın işlenmesi, failin maksadına ulaşması ve fiilin vücut organlarının verilmesi maksadıyla işlenmesi hallerinin ağırlatıcı sebep olarak maddede yer alması daha isabetli olurdu.

\section{VII- MÜEYYIDE}

Suçun basit şekli için kanunurı öngördüğü ceza beş yıldan on yıla kadar ağır hapis ve bir milyar liradan az olmamak izere ağı para cezasıdır. Görüldüğü gibi kanun sadece özgürlüğü bağlayıcı ceza ile yetinmemiş, bununla birlikte ayrıca para cezası da öngörmüştür. Suçun örgüıliu olarak işlenmesi halinde ise, bu cezalau bir kat artınlarak verilecektir. Suç ile korunan hukuksal değer ile bu değeri korumak için öngörülen ceza miktarı karşılaştırıldı ğında muieyyidenin aşırı olmadı̆̆ söylenebjlecektir.

\section{SONUÇ}

Kanunumuza yeni girmiş olan ve bizim insan yağması veya sömürüsü olarak adlandırdığınız 201b maddesinde düzenlenen suçun, öncelikle kişi özgürlüğünü koruyan bir cürüm olduğunu söyleyebiliriz. Kişi özgürlïğü. temel olarak, kanunumuzun cürümlere ait ikinci kitabının ikinci babmın "şahsın hürriyeti aleyhinde işlenen cürümler" başıı̆ını taşıyan üçüincü faslında yer alan cürümler ile korunmaktadır. $201 \mathrm{~b}$ maddesi de, farklı maksatlarla, kişi özgürlüğüne yörnelebilecek ihlallere karşı bireyi korumak amacıyla kanunumuza girmiş olan bir hükümdür. Bu nedenle insan yağması suçunun iş ve çalışma özgürlügüne yönelik cürümler içerisinde değil, kişi özgưrlügüne yönelik cürümler içerisinde düzenlenmesi gerekirdi.

\footnotetext{
"özgenç/Şahin. s.468.
} 
Suçun oluşabilmesi için failin irade üzerinde tesir gösteren bir takım araç hareketler vasıtasıyla bir kimseyi tedarik etmesi, kaçırması, bir yerden başka bir yere götürmesi, sevk etmesi veya barındırması gerekir. Failin bu seçimlik hareketlerden herhangi birisini yapması ile birlikte suç tamamlanır. Araç hareketler maddede cebir ve şiddet, baskı, tehdit, kandırma, nüfuzu kötüye kullanma, kişiler üzerindeki denetim olanaklarından veya çaresizliklerinden yararlanarak rızalarını elde etme olarak belirtilmiştir. Bu araç ve asıl hareketler, suçun maddi unsurunu oluşturmaktadır. Suç mütemadi bir suç olduğu için, suçun tamamlanma ve bitme anı farkl olacaktır. Sözgelimi kaçırılan kişi üzerinde fiili hakimiyet kurulmakla suç tamamlanır ve fakat bitmez. Kaçırılan kişi özgürlüğüne kavuşuncaya kadar suç işlenmeye devam eder. Bu nedenle mütemadi suça bağlanan sonuçlar, $201 \mathrm{~b}$ maddesi bakımından gözönünde bulundurulmalıdır.

201b/3 maddesine göre, 18 yaşını doldurmamış çocuklara karşı suçun işlenmesi halinde, bu kimseler üzerinde araç hareketler kullanılmasa bile, suç oluşmaktadır. Bir başka ifadeyle 18 yaşını doldurmamış olanların maddede belirtilen maksatlarla kaçırılmaları, tedarik edilmeleri, başka bir yere götürülmeleri, sevk edilmeleri veya barındırılmaları suçun varlığı için yeterli olup, bu kimselere karşı bu hareketlerin cebir, şiddet, baskı, kandırma gibi iradeyi zorlayan vasıtalarla gerçekleştirilmesine gerek bulunmamaktadır. Bu suç bakımından yasa koyucu, 18 yaşını doldurmamış olanları, daha etkin bir şekilde belirtilen maksatlara karşı korumuş olmaktadır.

Bu suça asıl karakterini veren öğe suçun manevi unsurudur. Bu unsur suçu, benzer suçlardan ayırmaya yarar. Gerçekten failin yukarıda belirtilen hareketleri, bir kimseyi zorla çalıştırmak veya hizmet ettirmek, esarete veya benzer uygulamalara tabi kılmak ya da vücut organlarının verilmesini sağlamak maksadıyla yapması gerekir. İnsan yağması suçunun varlığı için failin belirtilen maksatlarla hareket ettiginin sabit olması gerekir. Ancak bu maksatların gerçekleşmiş olması şart değildir. Failin belirtilen maksatlarla suçun maddi unsurunu oluşturan hareketleri yapması yeterlidir. Maddede belirtilen maksatların ayrıca gerçekleştirilmesi halinde, bu durumun ayı bir suç oluşturup oluşturmadığını belirlemek için, bu maksatlar arasında bir ayrım yapmak gerekir. Şayet fail vücut organlarının verilmesi maksadıyla mağduru kaçırmış ve ayrıca maksadına da ulaşmışa, failin sorumluluğu hem $201 \mathrm{~b}$ maddesinden ve hem de unsurlarını taşıması halinde, Organ ve Doku Alınması, Saklanması ve Nakli Hakkında Kanunun 15. maddesinden veya müessir fiilden dolayı olacak ve cezalar içtima ettirilecektir. Buna karşın fail, zorla çalıştırmak veya hizmet ettirmek ya da esarete veya benzeri uygulamalara tabi kılmak maksadıyla hareket etmiş ve bu maksadını da fiiliyata geçirmişse, bu durumda suçun mütemadi olması nedeniyle failin yalnızca $201 \mathrm{~b}$ maddesinden dolayı cezalandırtlması gerektiği görüşündeyiz. 
$201 \mathrm{~b}$ maddesinin ikinci fikrasinda kanaatimizce lüzumsuz bir açıklamaya yer verilmişstir. Buna göre birinci fikrada belirtilen maksatlarla girişilen ve suçu oluşturan eylemler varsa, mağdurun rızası yok sayılacaktır. Kanaatimizce karışıklığa sebebiyet verebilecek bu hükmün maddeden çıkartılması isabetli olacaktır. Çünkü hem bir kimsenin belirtilen maksatlarla, cebir, şiddet, tehdit, baskı, kandirma gibi esasen kişinin rızasına karşı yönelen araç hareketlerin gerçekleşmesini aramak, hem de bunlara mağdurun rızasının olduğundan hareketle bu rızanın yok sayılacağ etmek çeliş̧ki oluşturacaktır.

Son olarak belirtelim ki $201 \mathrm{~b}$ maddesinde suçu etkileyen bal olarak yalnızca fiilin örgütlü olarak işlenmesinin belirtilmiş olması yetersizdir. Kanaatimizce fiilin 12 yaşından küçüklere karşı cebir veya tehdit ya da baskı gibi iradeyi etkileyen hareketlere başvurulmaksızın işlenmesj. failin maksadına ulaşması ve vücut organlarının verilmesi maksadıyla eylemin gerçekleştirilmesi suçun ağırlatıcı sebebi olarak yer almalıydı. 


\section{BİBLIYYOĞRAFYA}

Arslan, Çetin, "Memura Aktif Mukavemet Suçu", YD, C.28, sy.4, Ekim 2002.

Artuk, Mehmet Emin/Gökcen, Ahmet/Yenidünya, A. Caner, Ceza Hukuku Genel Hükümler, Birinci Kitap, Ankara, 2002.

Artuk, Mehmet Emin/Gökcen, Ahmet/Yenidünya, A. Caner, Ceza Hukuku Özel Hükümler, 3. Baskı, Ankara, 2002.

Büyük Türkçe Sözlük (Hazırlayan: D. Mehmet Doğan), 11. Baskı, Istanbul, 1996.

Centel, Nur, Türk Ceza Hukukuna Giriş, Ístanbul, 2001.

Cihan, Erol, Cebir Kullanma Cürmü (TCK. m.188), Istanbul, 1978, s.49-51.

Daregenli, Vesile Sonay, "Tehlike Suçları", Prof. Dr. Sahir Erman'a Armağan, İstanbul, 1999.

Demirbaş, Timur, Ceza Hukuku Genel Hükümler, Ankara, 2002.

Dönmezer, Sulhi, Umumi Adab ve Aile Nizamı Aleyhinde Cürümler, İstanbul, 1950 .

Dönmezer, Sulhi/Erman, Sahir, Nazari ve Tatbiki Ceza Hukuku, Genel Kısım, C.I, 13. Bası, İstanbul, 1997.

Dönmezer, Sulhi/Erman, Sahir, Nazari ve Tatbiki Ceza Hukuku, Genel Kısım, C.II, 12. Bası, İstanbul, 1999.

Erem, Faruk, Ümanist Doktrin Açısından Türk Ceza Hukuku Özel Hükümler, C.IV, 3. Bask1, Ankara, 1985.

Erem, Faruk, Ümanist Doktrin Açısından Türk Ceza Hukuku, Özel Hükümler, C.III, 3. Bask1, Ankara, 1985.

Erman/Özek (Sahir Erman), Ceza Hukuku Özel Bölüm, Kişilere Karşı İlenen Suçlar, İstanbul, 1994.

İçel, Kayıhan, Suçların İçtimaı, İstanbul, 1972.

İçel, Kayıhan/Sokullu-Akıncı, Füsun/özgenç, İzzet/Sözüier, Adem/Mahmutoğlu, Fatih $\mathbf{S} /$ Ünver, Yener, İçel Suç Teorisi, 2. Kitap, 2. Bası, \stanbul, 2000.

Majno, Ceza Kanunu Şerhi. Türk ve İtalyan Ceza Kanunları, C.2, Ankara, 1978. 
Önder, Ayhan, Ceza Hukuku Genel Hükümler, C.II-III, İstanbul, 1992.

Önder, Ayhan, Türk Ceza Hukuku Özel Hükümler, 4. Bası, İstanbul, 1994.

Özgenç, İzzet/Şahin, Cumhur, Uygulamalı Ceza Hukuku, 3. Bası, Ankara, 2001.

Öztürk, Bahri/Erdem, Mustafa Ruhan/Özbek, Veli Özer, Öztürk Uygulamalı Ceza Hukuku ve Emniyet Tedbirleri Hukuku, 5. Baskı, Ankara, 2001 .

Öztürk, Bahri/Özbek, Veli Özer/Erdem, Mustafa Ruhan, Öztürk Uygulamalı Ceza Muhakemesi Hukuku, 6. Baski, Ankara, 2001.

Sancar, Türkan Yalçm, Müteselsil Suç, Ankara, 1995.

Schönke, Adolf/Schröder, Horst, Strafgesetzbuch Kommentar, 20. Auflage, München, 1980. 1999.

Soyaslan, Doğan, Ceza Hukuku Özel Hükümler, 3. Baskı, Ankara,

Tezcan, Durmuş / Erdem. Mustafa Ruhan, Teorik ve Pratik Ceza Özel Hukuku, 2.Bası, Izmir, 2002.

Toroslu, Nevzat, Cürümlerin Tasnifi Bakımından Suçun Hukuki Konusu, Ankara, 1970. s.1094.

Türkçe Sözlük 2 (Türk Dil Kurumu) Yeni Bask1, Ankara, 1988.

Ünver. Yener, Ceza Hukukuyla Korunması Amaçlanan Hukuksal Değer, Ankara, 2003.

Wessels, Johannes/Hettinger, Michael, Strafrecht Besonderer Teil//, Straftaten gegen Persönlichkeits- und Gemeinschaftswerte, 23.. neubearbeitete Auflage. Heidelberg, 1999. 